\title{
Feasibility of Using a High- Level Waste Canister as an Engineered Barrier in Disposal
}

S. C. Slate

S. G. Pitman

J. F. Nesbitt

W. L. Partain

August 1982

Prepared for the U.S. Department of Energy under Contract DE-AC06-76RLO 1830

Pacific Northwest Laboratory Operated for the U.S. Department of Energy by Battelle Memorial Institute 


\title{
DISCLAIMER
}

This report was prepared as an account of work sponsored by an agency of the United States Government. Neither the United States Government nor any agency thereof, nor any of their employees, makes any warranty, express or implied, or assumes any legal liability or responsibility for the accuracy, completeness, or usefulness of any information, apparatus, product, or process disclosed, or represents that its use would not infringe privately owned rights. Reference herein to any specific commercial product, process, or service by trade name, trademark, manufacturer, or otherwise, does not necessarily constitute or imply its endorsement, recommendation, or favoring by the United States Government or any agency thereof. The views and opinions of authors expressed herein do not necessarily state or reflect those of the United States Government or any agency thereof.

\author{
PACIFIC NORTHWEST I.ABORATORY \\ operated by \\ BATTELLE \\ for the \\ UNITED STATES DEPARTMENT OF ENERGY \\ under Contract DE-AC06-76RLO 1830
}

\begin{tabular}{|c|c|}
\hline \multicolumn{2}{|c|}{ Printed in the United States of America } \\
\hline \multicolumn{2}{|c|}{ Available from } \\
\hline \multirow{3}{*}{\multicolumn{2}{|c|}{$\begin{array}{c}\text { National Technical Information Service } \\
\text { United States Department of Commerce } \\
5285 \text { Port Royal Road } \\
\text { Springfield, Virginia } 22151\end{array}$}} \\
\hline & \\
\hline & \\
\hline \multirow{2}{*}{\multicolumn{2}{|c|}{$\begin{array}{l}\text { NTIS Price Codes } \\
\text { Microfiche A01 }\end{array}$}} \\
\hline & \\
\hline \multicolumn{2}{|c|}{ Printed Copy } \\
\hline & Price \\
\hline Pages & Codes \\
\hline $001-025$ & $\mathrm{~A} 02$ \\
\hline $026-050$ & $\mathrm{~A} 03$ \\
\hline $051-075$ & $\mathrm{~A} 04$ \\
\hline $076-100$ & $\mathrm{~A} 05$ \\
\hline $10:-125$ & $\mathrm{~A} 06$ \\
\hline $126-150$ & $\mathrm{~A} 07$ \\
\hline $151-175$ & $A 08$ \\
\hline $176-200$ & A09 \\
\hline $201-225$ & A010 \\
\hline $226-250$ & $A 011$ \\
\hline $251-275$ & $\mathrm{~A} 012$ \\
\hline $276-300$ & $\mathrm{~A} 013$ \\
\hline
\end{tabular}


PNL-4266

UC-70

FEAS IB ILITY OF USING A HIGH-LEVEL WASTE CANISTER AS AN ENGINEERED BARRIER IN DISPOSAL

S. C. Slate

S. G. Pitman

J. F. Nesbitt

W. L. Partain (a)

August 1982

Prepared for the

U. S. Department of Energy

under Contract DE-AC06-76RLO 1830

Pacific Northwest Laboratory

Richland, Washington 99352

(a) Sage Technical Associates, Richland, Washington. 

The Pacific Northwest Laboratory (PNL) has assessed the design of a highlevel waste (HLW) canister that can separate $H L W$ glass from the repository ground water for a long-term period. This durable, load-bearing, "barrier" canister may be an economical alternative to a more complex waste package made up of the conventional HLW canister placed in a metal overpack which is placed in a bentonite-lined borehole.

There are two major assumptions underlying this study. The first is that long-term separation of the waste form from the geology will be required, although the technical basis for such a requirement has not yet been established. Current federal regulations governing HLW storage canisters require only that they contain the HLW during processing, transportation, and for 90 days after emplacement in a repository. However, existing drafts of proposed federal regulations clearly incorporate a philosophy of increased isolation by the use of engineered barriers. This report focuses on canister integrity for 1000 years as being an upper limit of the containment period without endorsing this requirement. The second basic assumption is that canisters with reasonably thick walls of titanium or high-nickel alloys will sufficiently resist corrosion during long-term containment in any of the proposed repository geologies. This is a reasonable assumption based on general corrosion performance data, but other HLW programs are investigating the combined effects of increased temperature, high pressure, mineralized ground water, and radiation on the corrosion of these alloys.

The conceptual design for a barrier canister is very similar to the design of a conventional processing canister. The major differences are the use of appropriate alloys or thicker wall sections for corrosion resistance and the incorporation of design features to prevent the compressive forces in the repository from crushing the canister top where a void exists above the glass. The conceptual designs were assessed from the standpoint of manufacture, glass-fill processing, interim storage, and transportation. The specific areas where a demonstration of remote processing capability are recommended are:

- filling the canister void with a load-bearing material such as steel shot 
- lid-closure welding in a remotely operated facility using gastungsten-arc (GTA) or upset-resistance techniques

- nondestructive evaluation of filled canisters for verification of canister integrity.

A series of scoping tests were carried out on two titanium alloys and Inconel 625 to determine if the high temperature inherent in the glass-fill processing would seriously affect either the strength or corrosion resistance of these metals. This is a process-related concern unique to the barrier canister concept. The material properties were affected by the heat treatments which simulated both the joule-heated glass melter process (titanium alloys and Inconel 625) and the in-can melter (ICM) process (Inconel 625). However, changes in the material properties were generally within $20 \%$ of the original specimens. Accelerated corrosion testing of the heat treated coupons in a highly oxygenated brine showed basic corrosion resistance of titanium grade 12 and Inconel 625 to compare favorably with that of the untreated coupons. The titanium grade 2 coupons experienced severe corrosion pitting. These corrosion tests were of a scoping nature and suitable primarily for the detection of gross sensitivity to the heat treatment inherent in the glassfill process. They are only suggestive of repository performance since the tests do not adequately model the wide range of repository conditions that could conceivably occur.

(B) Registered trademark of the Huntington Al loys Corporation. 
INTRODUCTION • • • • •

PERFORMANCE CRITERIA . . . . . . . . . . . . . . . . . . 3

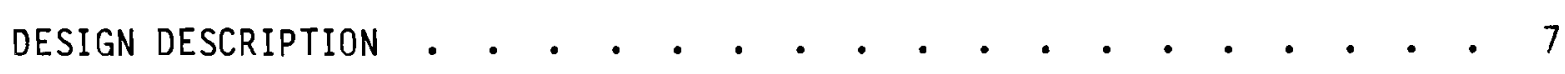

INTERFACE WITH HLW FACILITIES . • • • . . • • • • • • • 7

Repository Interface . • . . . . . • • . . . 7

Glass-fill Processing . . . . . . . . . . . 8

HLW Borosilicate Glass • • • • • • • • • • • . 12

BARRIER CANISTER CONCEPTS . . . . . . . . . . . . . 13

DESIGN DETAILS OF THE BARRIER CANISTERS • • • • • • • • • . 14

BARRIER CANISTER DESIGNS NOT STUDIED • . . • • • . . . . 18

DESIGN ASSESSMENT

MANUFACTURE . . . . . . . . . . . . . . . 21

Material Availability in Required Sizes and Alloys . . . . 21

Raw Material Costs for Canister . . . . . . . . 21

Availability of Industrial Standards for the Alloys . . . . 22

Ease of Working the Material (forming, casting, forging) . . 22

Relative Complexity of Welding . . . . . . . . . 22

$\mathrm{X}$-Ray and U1trasonic Inspection. . . . . . . . . 22

Heat Treatment, Mechanical Working, or Chemical Surface

Treatment . . . . . . . . . . . . . . 23

Industrial Experience with Similar Fabrications . . . . . 23

Codes Governing Canister Fabrication . . . . . . 23

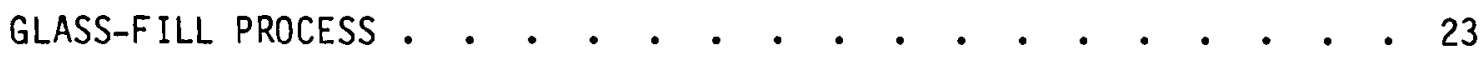

Codes Governing Canister Service Environment . • . . . 23

Degradation of Materials at Process Temperature . . . . 24

Temperature Effects on Canister Stress . . . . . . 25

Corrosion Due to Molten Glass . . . . . . . . 25 


\section{CONTENTS (contd)}

Decontamination . . . . . . . . . . . . . 26

Canister Void Filling Operation . . . . . . . . . 26

Lid Closure Weld . • • • . . . . . . . . 26

Overpack Compatability . . . . . . . . . . . 27

INTERIM STORAGE • • • • • • • • • • • • • • • • 28

Compatability with Water Storage . . . . . . . . 28

Compatibility with Air Storage . . . . . . . . . 28 TRANSPORTATION • • • • • • • • • • • • • • • • • . 28 REPOSITORY • . . . . . . . . . . . . . . . . 29

Corrosion Resistance . . . . . . . . . . . . 29

Repository Pressure. . . . . . . . . . . . . 31

Canister Retrieval . . . . . . . . . . . . 31

Repository Accidents . . . . . . . . . . . . . 31

Effect of Canister Material on Glass Leaching . . . . . . 32

Canister Material Attractiveness for Mining . . . . . 32

Quality Verification at Time of Emplacement. . . . . . 32

CONCLUSIONS AND RECOMMENDATIONS • • • • • . • • • • • • •

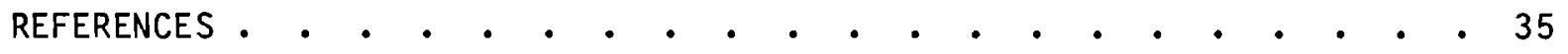

APPENDIX - Material EVAluations . . . . . . . . . . . . . . . A.1

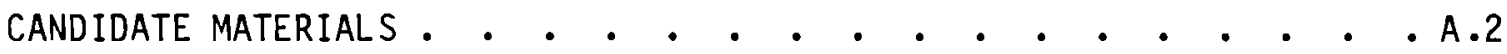

MECHANICAL AND CORROSION TEST PROCEDURES . • • • • . . . . . A.3

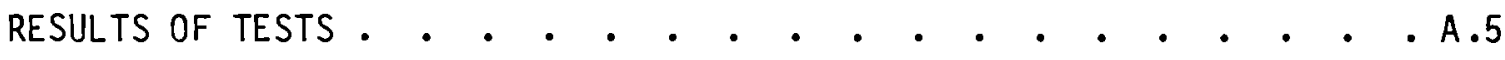

Impact Tests . . . . . . . . . . . . . . . A.5

Tensile Tests . . . . . . . . . . . . . A.7

Corrosion Tests . . . . . . . . . . . . . . . A.9

MATERIALS CONCLUSIONS . . . . . . . . . . . . . . A.15 


\section{FIGURES}

1 Conceptual Design of a Barrier Canister for HLW Glass . • • 15

2 Cross-Section of Fusion Weld Made with Gas Tungsten Arc Method $\quad 17$

3 Cross-Section of Closure Weld Made with the Upset-Resistance Method . . . . . . . . . . . . . 18

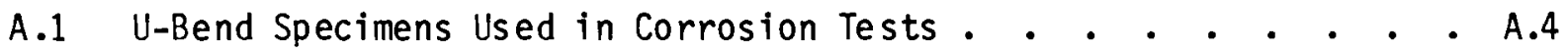

A.2 Fracture Surface of Titanium Grade 12 Charpy Impact Specimen, Showing Appearance of a Second Phase in the Material . . . . . A.7

A.3 Surface Pitting and Associated Cracking from Titanium Grade 2 Tensile Specimen . . . . . . . . . . . . . . . . A.11

A.4 Metallography of Titanium Grade 2 from Specimen Exposed to $600^{\circ} \mathrm{C}$ Thermal Cycle and to Brine . . . . . . . . . . . A.12

A.5 Largest Pits Found on Titanium Grade 2 Fixture. (Specimens are 1 in. wide) . . . . . . . . . . . . . . A.13

\section{TABLES}

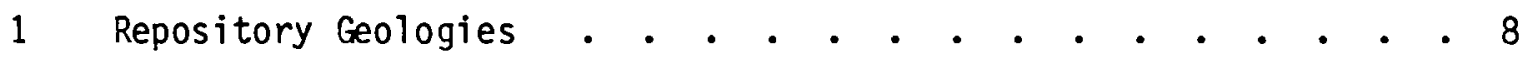

2 Canister Duty in the In-Can Melter Process . . . . . . . . 10

3 Summary of Process Stages for a Barrier Canister Containing $\mathrm{HLW}$ Glass • • • • • • • • • • • • • • • • • • 11

4 Range of Properties for HLW Borosilicate Glass . . . . . . 13

5 Canister Wall Thickness . . . . . . . . . . . . 16

6 Canister Strength at Service Temperature - . . • . . • 25

A.1 Results of Charpy Impact Tests . . . . . . . . . . . A.5

A.2 Results of Tensile Tests . • . • . . . . . . . . . A.8

A.3 Results of Corrosion Tests in Brine (mg/dm² yr) . • . • . . . A.10 


\section{INTRODUCTION}

The research and development programs on disposal of high-level nuclear waste ( $H L W$ ) have considered very durable overpack canisters that could separate the HLW from contact with any ground water for some extended period of time. The exact period has not been defined. Current regulations (Code of Federal Regulations, Title 10, Part 50, Appendix F) simply require the HLW be contained in a sealed container for transportation to a repository and for a minimum of 90 days after receipt. At the other extreme, a draft revision of a regulation from the U. S. Nuclear Regulatory Commission (Code of Federal Regulations, Title 10, Part 60) has proposed that the glass waste form be separated from any repository ground water by a system of engineered barriers for a period of $\sim 1000$ years. The engineered barrier/waste form would then act to reduce the release rate of radionuclides into the ground water over a much longer period of time.

The technical bases for the extent of additional isolation provided by different systems of engineered barriers is being developed under the National Waste Terminal Storage Program administered by the Battelle Memorial Institute's Office of Nuclear Waste Isolation (ONWI). Characterization of repository environments, including pressure and groundwater chemistry, combined with material corrosion studies and radionuclide migration studies under simulated repository conditions, will form the bases for design concepts for borehole backfill, canister overpack, and the primary processing canister.

If some degree of long-term containment is required, it may be possible to satisfy the requirement by an upgrade in the design of the primary processing canister. The objective of this report is to evaluate the feasibility of designing a process canister that could also serve as a barrier canister. To do this a general set of performance criteria is assumed and several metal alloys having a high probability of demonstrating high corrosion resistance under repository conditions are evaluated in a qualitative design assessment. This assessment encompasses canister manufacture, the glass-filling process, interim storage, transportation, and to a limited extent, disposal in a repository. Scoping tests were conducted to determine if the process temperatures have gross deleterious effects on either the mechanical properties or the corrosion rate in brine of some of the candidate alloys. 
PERFORMANCE CRITERIA

Recent efforts to establish design standards for HLW canisters include a study by Moore (1978), which proposed a set of acceptance criteria for a HLW package. In 1979 the Office of Nuclear Waste Isolation (ONWI) issued a set of proposed criteria (ONWI 1980) for a HLW package. Both of the documents were referenced as input to a proposed set of specifications (Westinghouse Electric Corp. 1980) for an engineered waste package system being developed by the Advanced Energy Systems Division of Westinghouse (W-AESD). Some parts of these proposed criteria appeared to be overly conservative in that the canister was apparently considered as the only barrier between the HLW glass and the environment during handling, interim storage, and transportation. In recognition of the fact that a HLW canister is always within a shielded controlled-ventilation enclosure and that it contains HLW in a very immobile waste form with no inherent dispersive driving force, it is appropriate to take a new look at proposed criteria to ensure they are consistent with other aspects of the nuclear fuel cycle.

The criteria for the long-term durability of the canister either alone or as part of a waste package were heavily influenced by drafts of proposed regulations by the U. S. Nuclear Regulatory Commission (Code of Federal Regulations, Title 10, Part 60, 1980) and the Environmental Protection Agency (Code of Federal Regulations, Title 40, Part 191, 1979). These regulations assume repository studies will indicate a need to assure long-term (up to 1000 year) separation of the waste form from the geology by means of engineered barriers and control of release rates by backfill buffer materials over a much longer period of time. The question of how much isolation is really required is being addressed by the Systems Studies on Engineered Barriers Program sponsored by ONWI. Two reports (Cloninger, Cole, and Washburn 1980; Cloninger and Cole 1981) have modeled radionuclide release and transport from spent fuel in repositories of salt, basalt, and granite. A similar study for HLW glass is being completed. The studies indicate that absolute containment by means of a barrier canister is not as important as controlling the release rate of the radionuclides. The controlled release rate is a function of the waste form, any clay backfills, and the near-field effects in the repository media. In view of these results future versions of the government regulations referenced above are expected to be less restrictive. 
This report studies the feasibility of designing processing canisters that can be retrieved after emplacement and which can serve as long-term (100 to 1000 year) barriers. However, these criteria are assumed only for the purpose of this feasibility study; it is not the intent of this report to propose these criteria as actual requirements.

This report evaluates the barrier canister designs according to the following design philosophy:

- Manufacture. The canisters must be fabricated by a vendor having an approved QA plan which ensures material is traceable, fabrication procedures are followed and final canister quality can be verified by a system of records, inspections (including weld $x$-rays), and tests.

- Filling Process. The canisters must be capable of withstanding rapid thermal cycling, large temperature gradients and lifting forces while being filled with molten glass in a remotely-operated facility. Post-fill processing includes closure lid welding, leak testing, decontamination, and inspection.

- Interim Storage. The canisters may be placed in interim storage for periods up to 50 years. The storage medium may be treated water for short periods followed by air storage over longer periods, or totally air storage. The loss of canister integrity under these conditions should be an unusual occurrence.

- Transportation. The canister will be transported in a shielded shipping cask. The canister design must accommodate both expected loads and impacts during cask loading operations and also survive unusual occurrences without gross breaching.

- Repository Disposal. The canister should maintain its integrity under expected repository conditions to withstand a retrieval operation within 25 to 150 years of emplacement. Also, integrity should be maintained sufficiently to physically separate the HLW form from the repository ground water for a long-term containment period of 100 to 1000 years. Both criteria must be met with a high degree of assurance. 
The design philosophy must ultimately be transformed into a set of specific design criteria which may be in the form of regulations or standards. For the purpose of this report we have evaluated the conceptual designs for the barrier canisters against a list of detailed requirements for each of the stages in the life history of the canisters. This evaluation is presented in the Design Assessment section.

The performance criteria for a barrier canister are an extension of those for a conventional HLW canister. The major differences are the requirements that a barrier canister must withstand both the corrosive environment and the imposed pressures within the repository. This, in turn, implies that a higher degree of quality assurance will be required during the barrier canister phases of manufacture, glass-filling, storage, and transportation. 



\section{DESIGN DESCRIPTION}

There are currently four types of repository geologies under investigation. They can be divided into two groups based on their corrosive potential. The brine in a salt repository is the most corrosive environment, while basalt, granite, and tuff ground waters are passive by comparison. Based on general corrosion knowledge, titanium alloys and high-nickel alloys should be capable of meeting long-term containment corrosion criteria in both salt and the passive geologies. The ferrous alloys may be adequate for the passive geologies in reasonable wall thicknesses and one design is included for evaluation in this study.

INTERFACE WITH HLW FACILITIES

Summaries of descriptive information for the candidate repository geologies, the HLW immobilization process and the HLW glass characteristics are included as interface requirements which affect the design of the barrier canister.

Repository Interface

The repository designs and associated characterization of the geological environments are being carried out by several different organizations. Draft reports of the interim reference repository conditions for a nuclear waste repository in salt, granite, basalt, and tuff have been issued by the Reference Repository Conditions Interface Working Groups (Raines et al. 1980), an ad-hoc IWG established by the National Waste Terminal Storage (NWTS) Program's Isolation Interface Control Board (I-ICB). The principal interface parameters affecting design requirements are given in Table 1 for the four repository geologies. Apart from the corrosion requirements imposed by each repository, the pressure to which the canisters are subjected is the principal parameter impacting canister design. The pressure can arise from several sources. There is a lithostatic pressure due to the creep of the rock. Only salt exhibits this in the time frame of interest. For hard rock repositories the pressure is due to the hydrostatic head, which depends on the ground-water level at the site. This has been conservatively assumed to be at ground leve 1 . 
TABLE 1. Repository Geologies

\begin{tabular}{|c|c|c|c|c|}
\hline Characteristics & Salt & Granite & Basalt & Tuff \\
\hline \multicolumn{5}{|l|}{$\begin{array}{l}\text { External Canister } \\
\text { Pressure }\end{array}$} \\
\hline Lithostatic, $\mathrm{MPa}$ & 16.2 & NP & NP & NP \\
\hline Hydrostatic, $\mathrm{MPa}$ & 6.0 & 10 & 11 & 8 \\
\hline Vertical Load, MPa & (a) & NP & NP & NP \\
\hline $\begin{array}{l}\text { Backfill Swelling, } \\
\text { MPa }\end{array}$ & (b) & NA & NA & NA \\
\hline \multicolumn{5}{|l|}{ Engineered Backfill } \\
\hline Required for $<1000 \mathrm{yr}$ & No & $\begin{array}{l}\text { Improved K } \\
\text { Over Crushed } \\
\text { Granite }\end{array}$ & $\begin{array}{l}\text { Crushed } \\
\text { Basalt }\end{array}$ & $\begin{array}{l}\text { Not Included } \\
\text { at This Time }\end{array}$ \\
\hline Required for $>1000 \mathrm{yr}$ & No & No & No & No \\
\hline \multicolumn{5}{|l|}{ Thermal Constraints } \\
\hline $\begin{array}{l}\text { Recommended Thermal } \\
\text { Area Loading, W/m² }\end{array}$ & 37.5 & 25 & 25 & 25 \\
\hline $\begin{array}{l}\text { Maximum Cannister Heat } \\
\text { Fux, } W / m^{2}\end{array}$ & 750 & 750 & 750 & 750 \\
\hline $\begin{array}{l}\text { Maximum Rock Tem- } \\
\text { perature, }{ }^{\circ} \mathrm{C}\end{array}$ & 250 & 165 & $\sim 200$ & 140 to 225 \\
\hline Corrosion Potential & High & Low & Low & Low \\
\hline Repository Depth, m & 600 & 1000 & 1100 & 800 \\
\hline
\end{tabular}

(a) Included as part of the lithostatic load.

(b) Crushed salt assumed as backfill.

NP Not predicted to be a significant load within the first 1000-yr period.

NA Not applicable unless precompacted bentonite backfill is used.

$\mathrm{K}$ Thermal conductivity.

Other forces have been postulated which may be larger than the hydrostatic or lithostatic pressure, but they can be eliminated by proper repository design. These forces include overburden vertical load, water vaporization, and backfill swelling. A vertical load from the column of overburden rock is recognized as a potential pressure source, but again experience indicates it will not be a significant factor in the first several thousand years. The pressure due to water vaporization in a sealed hole can give rise to large pressures if there are no paths or cracks for venting. Such pressurization is not considered a viable pressure source since its occurrence is unlikely, and 
repository safety considerations will require that the borehole design be vented should further studies show such pressurization occurs. The pressure due to swelling of a backfill such as bentonite could lead to large pressures on the canister if not sized properly.

Therefore, the hydrostatic pressure is the design pressure for granite, basalt, and tuff repositories, while the lithostatic pressure governs the salt repository pressure.

Glass-Fill Processing

Two principal processes for producing HLW glass have been developed in the United States. These are a spray calciner coupled to an in-can melter (SC/ICM) and a joule-heated glass melter (JHGM), which is also referred to as a ceramic melter because the glass melting is carried out in a refractorylined cavity. The JHGM can receive the HLW in a dried, calcined form from a spray calciner or as a concentrated slurry. In the latter case, the system is often termed the liquid-fed ceramic melter (LFCM). The ICM system requires that the calcined HLW and the glass frit be melted in the heated canister to form the resulting HLW glass.

The liquid-fed JHGM is currently considered to offer the most processing advantages, although special situations could favor use of the ICM process. The liquid-fed JHGM has been recommended for HLW solidification at the Savannah River Plant and the Western New York Nuclear Service Center. An outline of canister process history for both the ICM and the JHGM processes will be given here to serve as a basis for evaluating each barrier canister concept for its compatibility with the two processes.

In order to achieve continuous operation with the SC/ICM process, two canister furnaces are required for each spray calciner. The sequence of events describing the canister process history, including the approximate time intervals, is given in Table 2. The time intervals are variable and will be influenced by process upsets. For example, the canister design should be capable of withstanding up to 40 hours at the process temperature without serious degradation from glass attack, oxidation, or creep. 
TABLE 2. Canister Duty in the In-Can Melter Process

\begin{tabular}{|c|c|c|}
\hline Duty & Time, $h$ & Description \\
\hline Load Furnace & 0.5 & Place the Empty Canister in the ICM Furnace \\
\hline Preheat & 2 & Bring the Canister up to $1050^{\circ} \mathrm{C}$ \\
\hline Glass-Fil1 & 25 & $\begin{array}{l}\text { Feed Calcined HLW Solids and Glass Frit into } \\
\text { Canister to Form HLW Glass }\end{array}$ \\
\hline Fining & 2 & $\begin{array}{l}\text { Al low HLW Glass to Homogenize and to Melt any } \\
\text { Agglomerations of Calcined HLW Solids }\end{array}$ \\
\hline Furnace Cool & 4 & $\begin{array}{l}\text { Use Forced Air to Bring the Canister Wall } \\
\text { Temperature Down to } \sim 700^{\circ} \mathrm{C} \text { to Permit Canister } \\
\text { Changeout }\end{array}$ \\
\hline
\end{tabular}

Unload Furnace $\quad 0.5$ Remove Filled Canister and Place in a Controlled Cooling Rack

In the JHGM process the glass melting is carried out in the electric melter, and the canister is used merely to catch and contain the molten glass as it is airlifted or poured from the melter. While it is not necessary to preheat the canister, it will be held in a temperature-controlled retort and allowed to reach 400 to $600^{\circ} \mathrm{C}$ as the glass is poured. Allowing the canister temperature to rise to the softening point of the glass prevents void formation in the glass, which might occur if there is too much cooling. The glass pouring takes from 20 to 30 hours for the reference sized canister $10.6 \mathrm{~m} \mathrm{dia}$ by $3 \mathrm{~m}$ long). The glass formation rate is determined by the melter size and power density. This is in contrast to the ICM process, where the glass formation rate is determined by the maximum heat transfer rate into the canister from the surrounding furnace heater units.

There is no glass fining or canister cooldown in the JHGM process prior to canister removal from the retort beneath the melter. After being unloaded the canister is placed in a controlled-cooling rack.

After the canisters are unloaded and placed in the controlled-cooling rack, the sequence of canister duty is identical for each process. A complete summary of canister duty, applicable to either glass formation process, is given in Table 3. The constraints listed in Table 3 are addressed in detail in the Design Assessment section. 


\section{TABLE 3. Summary of Process Stages for a Barrier Canister}

Containing HLW Glass

\begin{tabular}{|c|c|c|}
\hline Process Step & Description & Constraint \\
\hline Fabricate Canister & $\begin{array}{l}\text { Build to Specifications } \\
\text { and Control Quality }\end{array}$ & $\begin{array}{l}\text { Material Grades and Integrity, } \\
\text { Size and Shape, Dimensional } \\
\text { Consistency, Personnel Qualifica- } \\
\text { tions, Q.A. Documentation }\end{array}$ \\
\hline Fill Canister & $\begin{array}{l}\text { Duty Depends on Selection } \\
\text { of ICM or JHGM Process }\end{array}$ & $\begin{array}{l}\text { Thermal Cycling, Maximum Process } \\
\text { Temperature, Corrosion by Glass, } \\
\text { Canister Oxidation }\end{array}$ \\
\hline Cool Glass & Cool at Controlled Rate & $\begin{array}{l}\text { Cooling Rate, Cracking and Glass } \\
\text { Devitrification, Canister Mate- } \\
\text { rial Sensitivity or Stresses }\end{array}$ \\
\hline Move Canister & Transport In-Cell & $\begin{array}{l}\text { Stresses in Canister, Potential } \\
\text { Drop or Impact, Temperature of } \\
\text { Canister, Remote Transport }\end{array}$ \\
\hline Fill Canister Void & $\begin{array}{l}\text { Fill the Void at the Top } \\
\text { of the Canister with } \\
\text { Steel Shot }\end{array}$ & $\begin{array}{l}\text { Remote Operation, Fill Level } \\
\text { Verification }\end{array}$ \\
\hline Close Canister & Make Leak-Tight Seal & $\begin{array}{l}\text { Canister Temperature, Remotely } \\
\text { Sealable, Seal Must Withstand } \\
\text { Design Loads and Pressures, } \\
\text { Assurance of Liquid-Tight Seal }\end{array}$ \\
\hline $\begin{array}{l}\text { Inspect and Label } \\
\text { Canister }\end{array}$ & $\begin{array}{l}\text { Inspect and Establish } \\
\text { Canister Identity }\end{array}$ & $\begin{array}{l}\text { Corrosion Resistance, Remote } \\
\text { Operation, Q.A. Documentation, } \\
\text { Process Control }\end{array}$ \\
\hline $\begin{array}{l}\text { Decontaminate } \\
\text { Canister } \\
\text { Provide Interim } \\
\text { Storage for Canister }\end{array}$ & $\begin{array}{l}\text { Clean Canister Exterior } \\
\text { Store in Water Basin or } \\
\text { Cool with Convective Air }\end{array}$ & $\begin{array}{l}\text { Material Compatibility, Removal } \\
\text { of Contamination } \\
\text { Thermal Shock, Weld Leak, Corro- } \\
\text { sion, Oxidation, Water Treatment, } \\
\text { Quality Verification, Lifetime in } \\
\text { Interim Environment }\end{array}$ \\
\hline Load and Transport & $\begin{array}{l}\text { Move by Rail or Truck in } \\
\text { Cask }\end{array}$ & $\begin{array}{l}\text { Remote Handling, Cask Interfaces, } \\
\text { Potential Drops or Impacts, } \\
\text { Potential Thermal Shock, Poten- } \\
\text { tial Internal Pressure, Internal } \\
\text { Pressure Buildup }\end{array}$ \\
\hline $\begin{array}{l}\text { Off Load and Surface } \\
\text { Storage }\end{array}$ & $\begin{array}{l}\text { Unload Cask, Inspect } \\
\text { Canister and Transport to } \\
\text { Lag Storage Environment }\end{array}$ & $\begin{array}{l}\text { Condition of Canister, Remote } \\
\text { Transportation, Potential Drop } \\
\text { or Impact }\end{array}$ \\
\hline
\end{tabular}


TABLE 3 (contd)

Process Step

Load and Transport

to Subsurface

Transport to

Emp 1 acement Area

Place Barrier

Canister in Hole

Dispose of Canister

Retrieve Canister
Description

Load in Cask and Place in Hoist Cage

Move in Transport Vehicle

Remove Canister from

Transfer Cask and Place

in Di sposal Hole

Seal Disposal Hole After Canister is in Place
Reexcavate to Top of Canister, Remove and Transport
Constraint

Remote Handling, Handling Loads, Impact Loads, Cask Interfaces, Cage Size, Hoist Capacity

Transport Loads

Handling Loads, Impact Loads, Remote Handling, Handling Equipment

Canister Size and Configuration, Thermal/Radiation Characteristics, Mechanical/Chemical Properties of Rock, Maintain Structura 1 Integrity (150 yr), Maintain Containment Integrity ( $<1000 \mathrm{yr})$, Presence of Water/Lithostatic Pressure $(0.27 \mathrm{MPa} / 10 \mathrm{~m})$ in Salt, Hydrostatic Pressure $10.1 \mathrm{MPa} /$ $10 \mathrm{~m}$ ) in Rock

Accessibility of Canister, Strength of and Stresses in Canister, Handling Loads and Equipment

HLW Borosilicate Glass

The HLW glass is a borosilicate formulation containing fission products and transuranics from the reprocessing of nuclear fuel. The radioactive components are typically only a small weight fraction of the glass, but there can be considerable variation in the glass formulation depending on the quantity and type of chemicals added to the waste stream during reprocessing. These variations are discussed in a reference description of commercial HLW (S1ate, Ross, and Partain 1981) and also apply to defense HLW.

The typical range of $H L W$ glass properties that are relevant to this feasibility study are given in Table 4. 
TABLE 4. Range of Properties for HLW Borosilicate Glass

$\begin{array}{ll}\text { Density: } & 2.6 \text { to } 3.2 \mathrm{~g} / \mathrm{cm}^{3} \\ \text { Thermal Expansion: } & 80 \text { to } 100 \times 10^{-7} /{ }^{\circ} \mathrm{C} \\ \text { Softening Temperature: } & 575 \text { to } 650^{\circ} \mathrm{C} \text { (viscosity }=4 \times 10^{7} \text { poise) } \\ \text { Devitrification Temperature: } & 500 \text { to } 950^{\circ} \mathrm{C} \\ \text { Melting Temperature: } & 1025 \text { to } 1150^{\circ} \mathrm{C} \\ \text { Thermal Conductivity: } & 0.8 \text { to } 1.3 \mathrm{~W} / \mathrm{m}-{ }^{\circ} \mathrm{K}\end{array}$

While borosilicate glass has been used as the reference waste form in this document, the conclusions are generally applicable for alternative waste forms such as glass marbles in a metal matrix, tailored ceramic billets or coated ceramic particles.

\section{BARRIER CANISTER CONCEPTS}

The waste package for a particular repository site will be designed by the contractor of that site. However, ONWI has several supporting efforts underway. These include a program by Westinghouse's Advanced Energy Systems Division to conduct a scoping design effort, partial results being still in the draft stage. In addition, the Waste Package Program is being conducted at PNL with the objective of developing a data base for various materials that may become part of the waste package. The data base will include the combined effects of corrosion, radiation and any resulting chemical reaction components on the materials being considered for waste packages.

Since barrier canisters are only one of the many possible concepts for a waste package and one which has not received a lot of preconceptual design effort, it is necessary to make some assumptions in order to carry out the primary objective, which is to examine the manufacture, process, and handling characteristics. We have assumed that a barrier canister would closely resemble the size and shape of the HLW glass processing canister. A screening test of a wide range of metal alloys capable of withstanding both processing conditions and long-term isolation in one or more of the repository geologies was beyond the scope of this study. We picked two titanium alloys, grade-2 and grade-12, and one high-nickel alloy, Inconel $625^{\circledR}$, as potential materials for a barrier canister in any of the geologies under study. In addition, carbon 
steel was considered a potential material for the less corrosive geologies (basalt, granite and tuff).

\section{DESIGN DETAILS OF THE BARRIER CANISTERS}

The basic design of the barrier canister is very similar for each of the proposed alloys. A reverse-dished, flanged tank end has been selected over a flat-plate bottom. The two principal advantages are a stable base unaffected by thermally induced bowing and a weld region above the corner, where any impact forces could be concentrated. The weld location, $\sim 5 \mathrm{~cm}$ from the bottom, will also facilitate quality verification testing. The side walls of the canister are either rolled plate with a seam weld or centrifugally cast. The top end of the canister is a flanged tark end with a single flange nozzle similar to the design proposed for defense HLW (DHLW) at the Savannah River Plant (Baxter 1981).

A schematic of the canister is shown in Figure 1. Typical dimensions are given for this conceptual design. The canister evaluation is carried out under the assumption that the canister diameter will range between $30 \mathrm{~cm}$ and $61 \mathrm{~cm}$ (12 to $24 \mathrm{in.).} \mathrm{The} \mathrm{length} \mathrm{is} \mathrm{assumed} \mathrm{to} \mathrm{be} 300 \mathrm{~cm}$ or less overal!, although it could be as much as $500 \mathrm{~cm}$. If a canister is filled to $90 \%$ of its capacity with the HLW glass and then topped off with steel shot, the canister weights will range from $750 \mathrm{~kg}$ for a thin-walled, $30 \mathrm{~cm}$ titanium canister to $3,700 \mathrm{~kg}$ for a $61 \mathrm{~cm}$ dia cast steel canister with $2.5 \mathrm{~cm}$ wall s. 


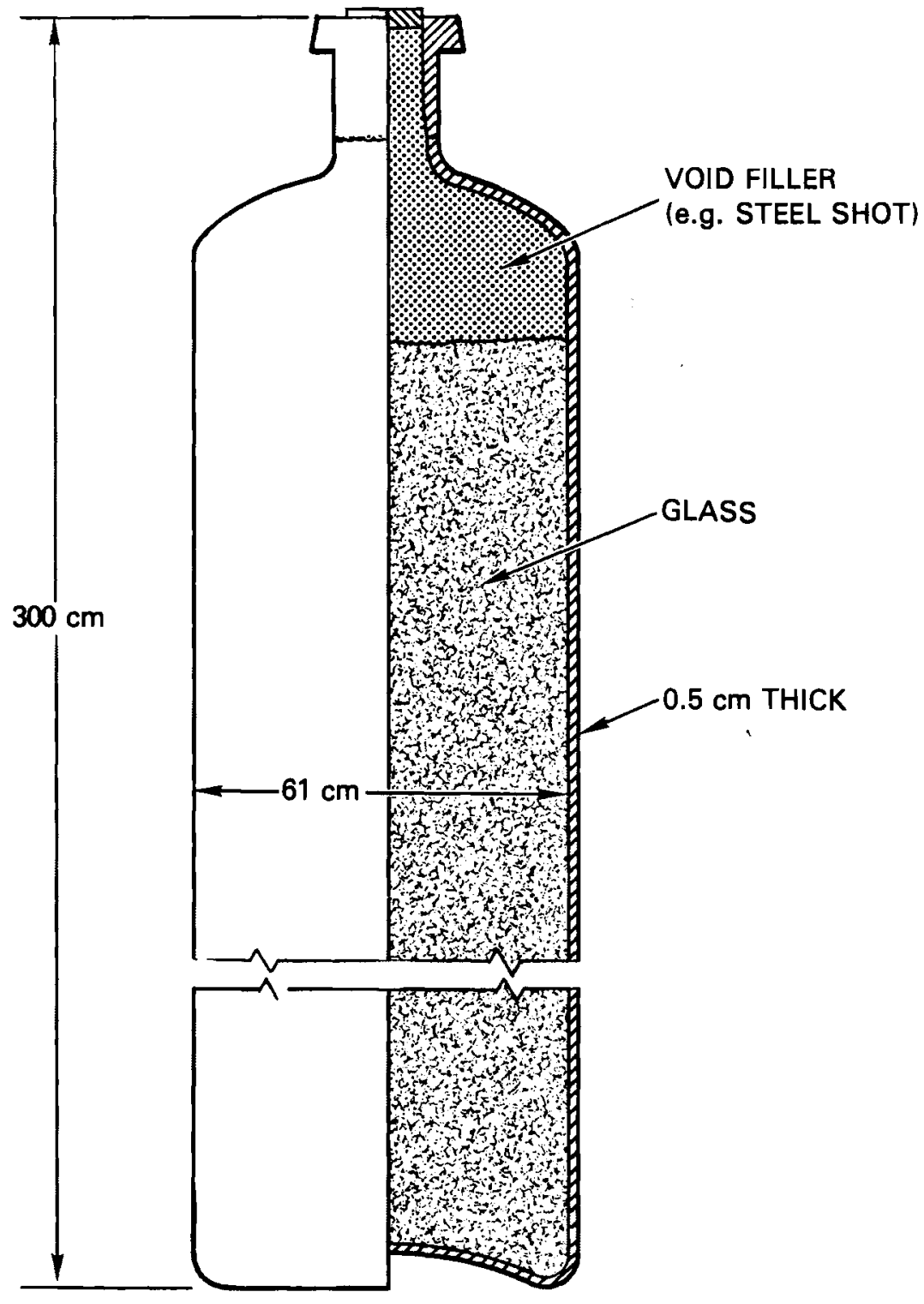

FIGURE 1. Conceptual Design of a Barrier Canister for HLW Gl ass

The wall thickness required for the barrier canister is a function of several factors. These include allowances for oxidation during processing, corrosion during the long-term disposal period, and impact damage and scratches during normal handling. The thickness must also provide sufficient strength to withstand significant creep at the process temperature. Many of the factors have not been well quantified. However, a considerable number of 
stainless steel, carbon steel, and Inconel processing canisters have been manufactured and filled with simulated HLW glass as part of the research and development (R\&D) for past and present HLW programs. From this experience a subjective choice of wall thicknesses for a matrix of canister materials and repository geologies is given in Table 5. Approximately 1 to $2 \mathrm{~mm}$ allowance for corrosion of titanium and Inconel is included in the wall thickness, while $\sim 2 \mathrm{~cm}$ of the carbon steel is included as corrosion allowance. These corrosion allowances are part of the assumptions necessary to carry out this study. More comprehensive programs such as the Waste Package Program sponsored by ONWI will ultimately provide a range of design values.

TABLE 5. Canister Wall Thickness

\begin{tabular}{llllll} 
& & \multicolumn{3}{c}{ Canister Wall } & Thickness, cm (a) \\
Barrier Canister & & Salt & Granite & Basalt & Tuff \\
Ticode 12 & & 0.6 & 0.5 & 0.5 & 0.5 \\
Titanium 2 & NR & 0.5 & 0.5 & 0.5 \\
Carbon Steel & NR & 2.5 & 2.5 & 2.5 \\
Inconel 625 & 0.6 & 0.5 & 0.5 & 0.5
\end{tabular}

(a) For a canister having nominal dimensions of $61 \mathrm{~cm} \mathrm{dia}$ by $300 \mathrm{~cm}$ length.

NR Not recommended.

A key element in barrier canister design is the accommodation of the pressures predicted in the repository. These pressures are summarized in Table 1 for the four repositories considered. There are several design approaches which could make the top region of the canister, normally void, strong enough to resist buckling from imposed stresses. The recommended technique, pending further evaluation, is to fill the void space with steel shot. This approach would transfer most of the external force to the waste form itself. Other potential design solutions include making the top end of the canister thicker with reinforcement ribs added inside the normally void region. Experiments are needed to evaluate these potential solutions.

The design of the fill nozzle and closure lid must take into account the interface with the spray calciner or JHGM as well as the need to perform all operations remotely. Selecting a welding process that can be carried out 
reliably, in-cell, is an important part of the design. The weld thickness must be at least equal to the corrosion allowance for the material. Two processes, gas-tungsten-arc (GTA) and upset resistance, are under active development for remote application. The GTA process can make a fillet lap weld on any of the proposed canister materials. However, the titanium weld would require additional weld surface preparation and inert gas shielding, as discussed in the Design Assessment section. A cross-section of a typical lid closure employing the GTA weld process is shown in Figure 2. Upset-resistance is a promising weld process that utilizes a pulse of high amperage, low voltage current in combination with an interference-fit closure lid that is forced into place as the contact surfaces are momentarily melted. This method has been recommended as the closure technique for Savannah River Plant defense canisters (Baxter 1981). A cross-section of the Savannah River plug weld is shown in Figure 3.

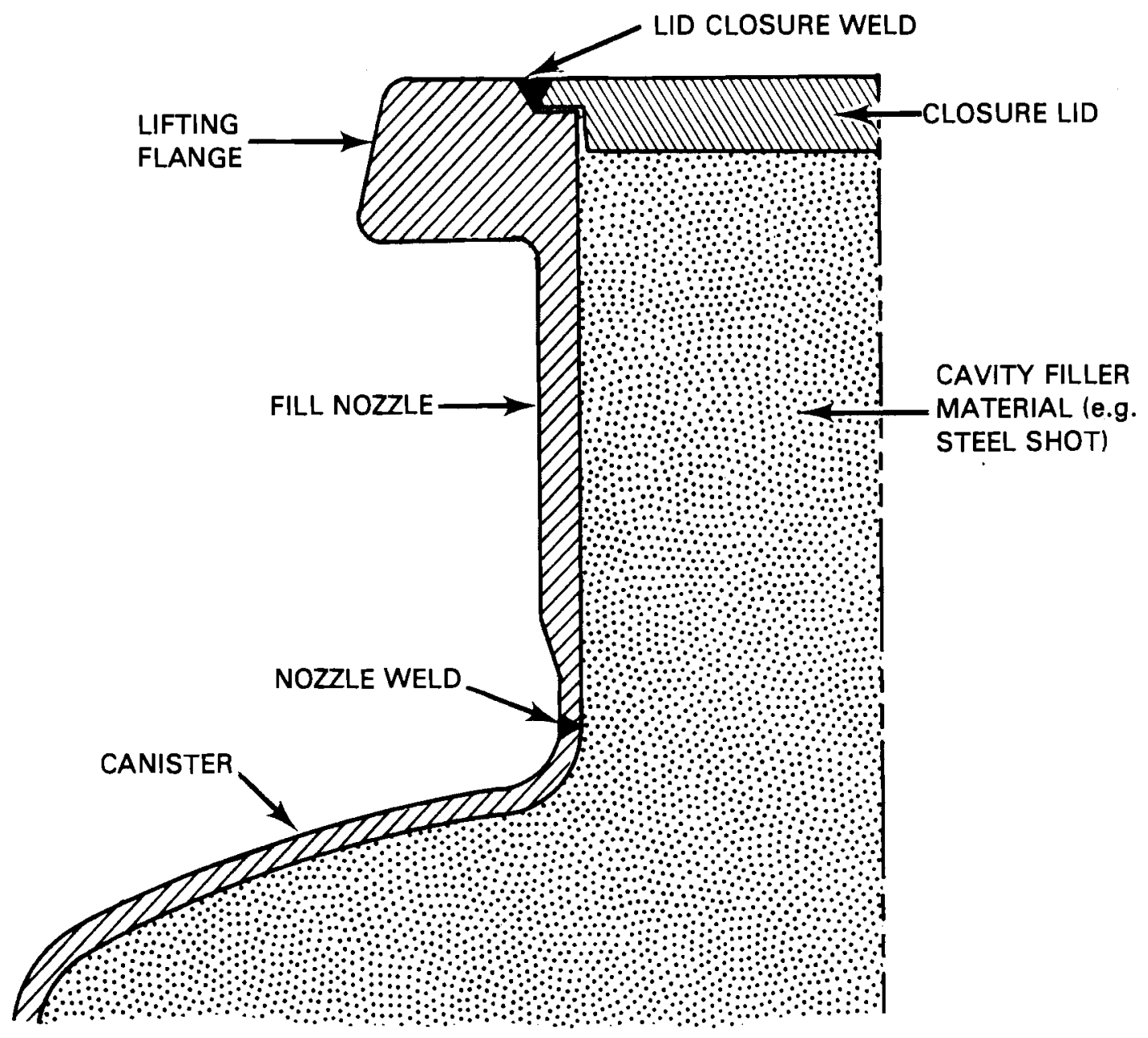

FIGURE 2. Cross-Section of Fusion Weld Made with Gas Tungsten Arc Method 


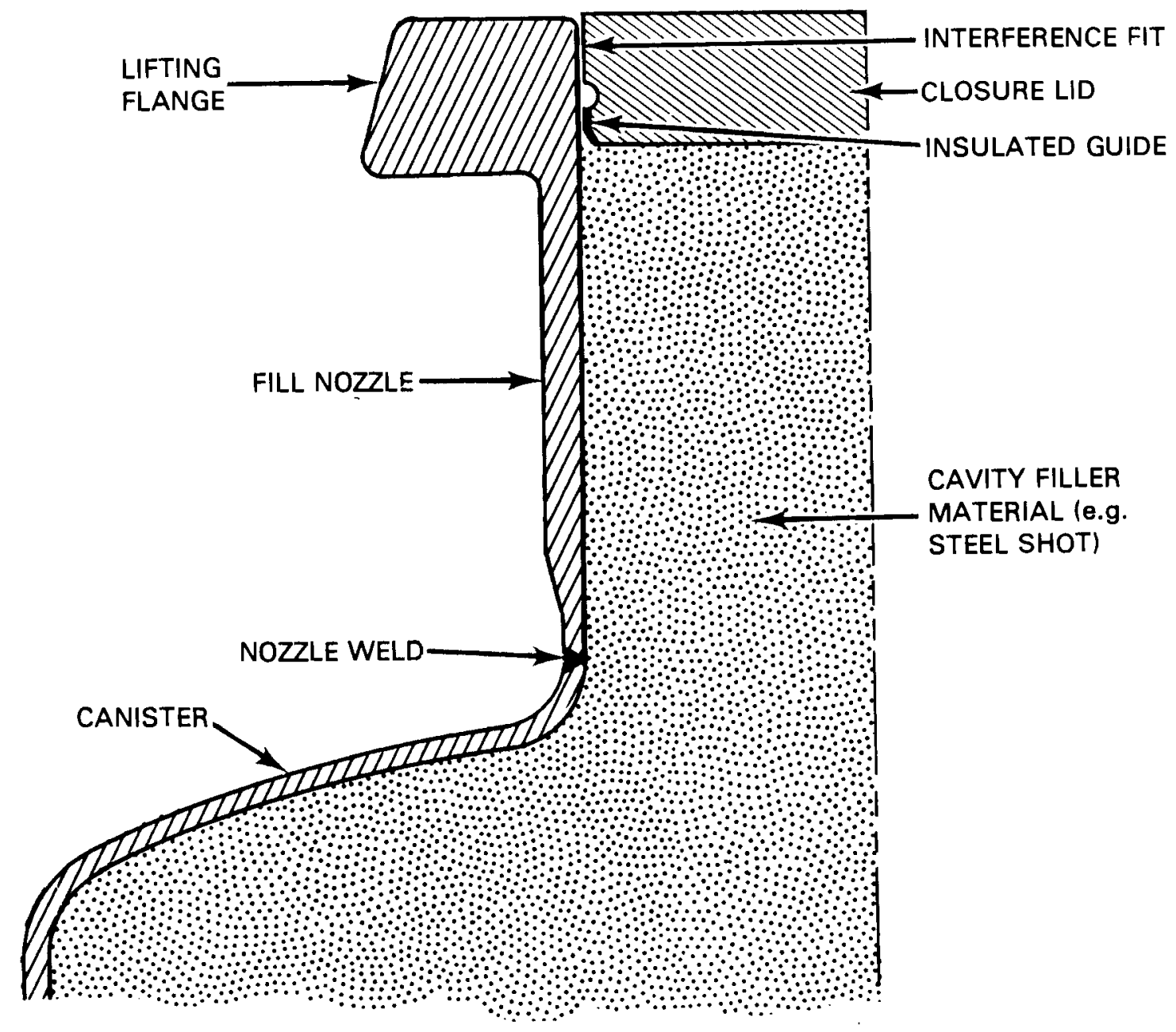

FIGURE 3. Cross Section of Closure Weld Made With the Upset-Resistance Method

A single flange on the nozzle serves as the canister handling fixture. Other designs demonstrated for conventional canisters include bails or pintles fabricated as part of the closure lid. The flange also serves as the grounding face for the upset-resistance welding technique.

\section{BARRIER CANISTER DESIGNS NOT STUDIED}

Other designs than those included in this report have been proposed as combination processing/barrier canisters. Cast iron of $\sim 1$ in. thickness may be an acceptable candidate as a barrier canister if used in the JHGM process and disposed of in basalt, granite, or tuff repositories. It was not included 
as part of this study because of the requirement that the canisters be cast and the difficulty in achieving a high quality weld without embrittlement. However, if carbon steel proves to be acceptable, the cast iron, which is similar in many aspects, should receive further study. A cast iron or carbon steel canister sheathed with a thin titanium sheet has been suggested. This design was not included in the feasibility study because it was judged that the increased cost of manufacturing and quality verification would offset the cost savings realized from reducing the titanium usage. The use of cast refractory shapes consisting of alumina has been proposed for TRU waste solidified by an ICM process. Such a canister could conceivably be produced for lower cost than the metal alloy canisters, but is judged to be too vulnerable to thermal shock and impact damage to serve as a HLW canister.

Canisters of ferrous alloys with sufficient wall thickness to withstand corrosion attack in a salt repository (using conservative models) were not considered as barrier canisters on the basis that it would be more practical to produce the glass in the conventional thin-wall processing canister and use the thicker ferrous alloy canisters as overpacks. 


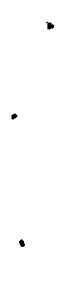




\section{DESIGN ASSESSMENT}

The feasibility assessment of the proposed barrier canister designs is based on a checklist of important design considerations and performance criteria. The checklist is broken down into the following phases of the canister's history: manufacture, glass-filling, interim storage, transportation and repository. The evaluation for each item on the checklist is carried out to the extent necessary to assess the feasibility of the barrier canister design, but the actual design effort will obviously require more in-depth analysis and, in some cases, additional research and development.

\section{MANUFACTURE}

The need for HLW canisters is foreseen as 10 to 20 per year for an R\&D period, increasing to 100 to 300 per year as limited production runs for the solidification of existing commercial and defense HLW are begun, and eventually reaching 1000 to 3000 canisters per year in the peak years of HLW disposal, assuming the current nuclear reactor deployment predictions (U.S. DOE 1980).

Material Availability in Required Sizes and Al loys

Clearly the ferrous alloys are readily available in the widest range of sizes and forms. Inconel and the titanium alloys are available in many standard sizes of plate. However, more lead time in procurement can be expected for Inconel and titanium, especially early in the R\&D stage, when only limited numbers of canisters are required. None of these alloys are considered strategic materials.

Raw Material Costs for Canister

Current cost estimates for the materials in a $60 \mathrm{~cm}$ dia by $300 \mathrm{~cm}$ long canister are as follows for the various designs: carbon steel ( $\$ 400)$, Inconel $(\$ 7,100)$, and titanium alloy $(\$ 3,800)$. These costs are based on weight only and do not include special forming, metalworking, fabrication costs, or quality assurance. Volume purchasing would be required to achieve these prices. The market cost of all metals, especially titanium, has fluctuated in recent years. Current prices are considered low. 
Availability of Industrial Standards for the Alloys

All of the alloys specified for barrier canisters are covered by industry standards. The American Society for Testing and Materials (ASTM) provides material specifications; many users, including the Department of Defense (DOD), have also established a body of specifications for all of these alloys. Individual specifications governing purity, heat treatment, mechanical working, surface treatment and other fabrication aspects can be tailored to the specific case of barrier canister manufacture.

Ease of Working the Material (forming, casting, forging)

On a relative basis the materials, rated in descending order of flexibility in manufacturing, are carbon steel, Inconel, and titanium. The carbon steel is very adaptable to almost any type of manufacturing technique. Inconel can be worked, but its toughness makes it more difficult to machine. The titanium is also easily formed, cast, or machined. It has some potential for pyrophoric ignition of small fines during machining and it is usually advantageous to use a heat-forming technique to reduce springback. It also has a tendency for galling.

Relative Complexity of Welding

The carbon steel is easily welded but does require annealing to minimize sensitization and embrittlement. Inconel is also easily welded but requires annealing to reduce grain growth. Titanium can be fusion welded but requires inert gas on both sides of the welded seam. Both the material and the filler wire should be cleaned in advance to minimize oxides and hydrides that would lead to embrittlement. The titanium grade 12 may suffer some loss of corrosion resistance in the weld region depending on temperature history, but this can be reversed by annealing. The lid closure weld is discussed separately in the following sections.

\section{X-Ray and Ultrasonic Inspection}

Al 1 materials can be inspected for voids and cracks by a combination of $x$-ray and ultrasonic inspection. The type of weld and its geometry usually have more effect on ease of inspection than the type of material. Obviously the thicker materials reduce the resolution of $x$-rays. Also, Inconel tends to rapidly attenuate ultrasonic waves, and the crystalline structure of Inconel welds can increase the difficulty of ultrasonic inspection. A relative 
ranking of the materials, taking into account the thickness, indicates titanium as the most easily inspected followed by carbon steel and Inconel. Heat Treatment, Mechanical Working, or Chemical Surface Treatment

While each of the canister designs will require some post-fabrication work such as stress annealing, pickling, or machining, no one design requires an inordinate amount of such work. No metalworking, such as shot peening of the surface, is foreseen as a fabrication requirement. Cast carbon steel canisters may require light machining to achieve a desired surface smoothness. Industrial Experience with Similar Fabrications

The fabrication efforts for all of the designs formed from plate are less complex than many other industrial applications of these materials. The canister and nozzle are straightforward extensions of common industrial experience. Actual canister fabrication experience has been gained in the construction of a number of canisters from various materials for R\&D purposes. Codes Governing Canister Fabrication

A review of the American Society of Mechanical Engineers (ASME) code for possible application to HLW canisters reached the following conclusions (Nuclear Services Corporation 1978): 1) of the various sections of the ASME Boiler and Pressure Vessel Code, Section III, Division I, Class 3 provides the most appropriate set of rules for fabrication; and 2) existing provisions of the ASME code are suitable to ensure canister quality at the time of fabrication, but are inadequate for the evaluation of the canister during glassfilling or repository residence.

GLASS-FILL PROCESS

The process temperature history of a barrier canister during glass fill by the JHGM method is within common industrial operating parameters. However, the higher temperature of the ICM process is a severe duty requirement for these materials. (Titanium and carbon steel are not considered as viable candidates.)

Codes Governing Canister Service Environment

In the assessment (Nuclear Services Corporation 1978) of the ASME code for applicability to HLW canister fabrication and service, the following conclusions were reached regarding service: 1) additional research is needed for 
evaluating canister materials performance under severe environments and for design verification by testing canisters under simulated service conditions, 2) the data developed in special research studies could form the basis of a new code subsection in subsection NH to ASME Section III, and 3) Code Case 1592-11 (Class 1--Components in Elevated Temperature Service) provides a useful framework for evaluating canister integrity during filling at elevated temperatures. Additional materials data is required, however, to qualify materials for temperatures reached during canister processing.

Degradation of Materials at Process Temperature

Mechanical properties of titanium alloys grade 2 and 12 and Inconel 625 were tested after the specimens had been heat treated with temperature histories duplicating the ICM process and the JHGM process. Details of the tests are given in the Appendix.

Only the Inconel 625 is being considered for the ICM process. Both the carbon steel and the titanium alloys oxidize rapidly at $1050^{\circ} \mathrm{C}$ and are not suitable for service at this temperature. The suitability of Inconel has been demonstrated during development of the SC/ICM system. Inconel surface oxidation occurs with very little spalling, although a small accumulation of oxide may occur in the furnace over a period of time.

Inconel toughness may actually increase after heat treatment at $1050^{\circ} \mathrm{C}$ with a corresponding increase in ductility. Studies (Simonen and Slate 1979) have also shown that creep will not be a significant problem for the relatively short period of time (20 to 30 hours) that the Inconel canister will be at the elevated temperature.

The JHGM process results in a maximum canister temperature of $\sim 600^{\circ} \mathrm{C}$. The carbon steel and Inconel canisters can easily accommodate this type of service without significant oxidation. Titanium grade 12 and titanium grade 2 can also accommodate this service temperature without excessive oxidation, but the titanium grade 12 is apparently subject to a time dependent separation of alloying agents at $\sim 400^{\circ} \mathrm{C}$. The change in structure may be reversible by heat treatment at $600^{\circ} \mathrm{C}$, but the typical slow cool of a canister filled with heat generating glass could result in more alloy separation. The effect of the material structure change appears to degrade the impact resistance significantly in titanium grade 2 and slightly in titanium grade 12 . Toughness 
changed only slightly for both titanium alloys undergoing heat treatment at $600^{\circ} \mathrm{C}$, but the ultimate strength was significantly decreased.

Temperature Effects on Canister Stress

The stress in canisters during processing is produced by a combination of lifting and handling loads, internal pressure, transient heating and cooling, differential thermal expansions of canister and glass, and impact loadings from low-probability accidents. Based on previous analyses (Simonen and Slate 1979), the maximum stresses in the canisters will be due to thermal expansion effects as opposed to anticipated internal pressure or lifting loads (accidents are considered separately). This is obviously a complex issue that does not lend itself to a relative ranking system. For the purpose of the feasibility study, the tensile strength of the various canister materials are given at their proposed service temperature in Table 6 . These values are then multiplied by the proposed canister thickness to give a figure of merit reflecting the relative margin of safety of the various canister designs.

TABLE 6. Canister Strength at Service Temperature

\begin{tabular}{|c|c|c|c|}
\hline Material & $\begin{array}{l}\text { Yield Tensile } \\
\text { Strength } \\
\end{array}$ & $\begin{array}{l}\text { Canister Wall } \\
\text { Thickness, cm } \\
\end{array}$ & $\begin{array}{c}\text { Figure of } \\
\text { Merit }\end{array}$ \\
\hline Carbon Stee $1\left(600^{\circ} \mathrm{C}\right)$ & 15,000 & 2.5 & 37,500 \\
\hline Inconel $\left(600^{\circ} \mathrm{C}\right)$ & 50,000 & 0.5 & 25,000 \\
\hline Inconel $\left(1050^{\circ} \mathrm{C}\right)$ & 10,000 & 0.5 & 5,000 \\
\hline Titanium Grade $2\left(600^{\circ} \mathrm{C}\right)$ & 17,000 & 0.5 & 8,500 \\
\hline Titanium Grade $12\left(600^{\circ} \mathrm{C}\right)$ & 25,000 & 0.5 & 18,500 \\
\hline
\end{tabular}

Corrosion Due To Molten Glass

This is primarily a question of Inconel corrosion in the ICM process since the glass is too viscous and nonreactive at $600^{\circ} \mathrm{C}$ to corrode any of the materials. Inconel alloys 601 and 690 have been routinely used in the JHGM as electrodes and thermowells for extended periods of time. Glass temperatures of up to $1150^{\circ} \mathrm{C}$ in the ICM have been experienced with Inconel 601 canisters without significant corrosion. 
Decontamination

A study of the decontamination methods best suited to HLW canisters (Nesbitt, Slate, and Fetrow 1980) indicates electropolishing is very effective in removing all contamination as well as oxides from carbon steels, stainless steels, and Inconel. While titanium was not tested, specimens of aluminum were found to be effectively decontaminated. There is no evidence that electropolishing will attack grain boundaries in the alloys. Therefore, all barrier canister concepts are rated equal on this point of comparison.

Canister Void Filling Operation

In filling a HLW canister with glass it is important to reduce the probability that the canister will be overfilled, thereby creating gross contamination of the canister and the process cell. The normal procedure is to leave a void at the top of the canister equivalent to $10 \%$ of the canister volume. One of the techniques for increasing the canister load-bearing capability is to fill this void so that repository pressures will not buckle the canister. Steel shot of different sizes has been proposed as a suitable fill material. All of the proposed barrier canister materials will be compatible with the steel shot. Detailed stress calculations will be necessary to examine the interaction of the canister and the steel shot as the canister is cooled. Carrying out this filling operation to a close tolerance in a remotely operated process needs to be designed and demonstrated.

Lid Closure Weld

The canister closure lid must be seated and welded remotely. Several methods have been proposed and demonstrated in nonradioactive mockups. The principal methods under current investigation are a GTA and a solid state weld process called upset-resistance. The latter uses a low-voltage, high-current pulse to melt a contact area between the fill nozzle and an interference-fit closure plug that is forced into place by a ram. The principal criteria for a closure lid weld process are that it can be carried out remotely with high reliability, that it requires minimum weld surface preparation and fitup, that the weld thickness be at least as thick as the corrosion allowance for the canister material, and that the welding process will not change the properties of the material as a result of the temperature history. 
Carbon steel can be welded by conventional arc welding or by the upsetresistance technique. A small amount of weld surface preparation is anticipated. The Inconel canister can also use either GTA or upset-resistance. For the Inconel ICM canister a moderate amount of weld surface preparation, including grinding, may be required to remove the oxidation layer. Lid closure welds for the titanium alloys can be either GTA or upset-resistance, although GTA requires special procedures. Titanium (especially grade 12) is sensitive to contamination by oxygen, oxides and nitrogen during fusion (GTA) welding, and the welding procedure will require careful cleaning of all titanium surfaces, including the weld wire, immediately prior to the welding operation as well as argon gas blanketing behind and above the hot weld region. Conducting the more complex welding operations for titanium in a remotelyoperated process cell may result in a higher percentage of defects than was realized with the other materials. The application of upset-resistance welding to titanium alloy canisters is under development at the Savannah River Laboratory. While the weld surfaces may still require some cleaning, the process does not require the inert gas blanketing. Sensitization of the titanium surrounding the weld will also be less in comparison to the GTA process.

Overpack Compatability

A barrier canister must be compatible with a secondary overpack which could be used as a means of corrective action for a defective canister. The overpack must serve as the primary barrier for the containment period and be of sufficient thickness to withstand repository forces without transferring the load to the defective barrier canister. A typical overpack design for a basalt, tuff or granite repository is a carbon steel canister having $5.1 \mathrm{~cm}$ thick walls. The same type of load-bearing carbon steel overpack protected by a thin titanium sheath would provide sufficent protection for a salt repository. Approximate weights of $60 \mathrm{~cm}$ dia barrier canisters containing glass that have a $5.1 \mathrm{~cm}$ (2 in.) thick steel overpack are carbon steel (7000 kg), Inconel $(6400 \mathrm{~kg})$ and titanium $(5900 \mathrm{~kg})$. No problems are foreseen that would preclude using an overpack canister to correct processing defects for any of the barrier canister designs. 
INTER IM STORAGE

The requirement for interim storage may arise because of delays in developing sufficient repository capacity or the solidification of HLW with such a short decay that an additional period of decay is necessary to meet thermal limitations imposed by the repository design. Naturally some period of onsite storage is anticipated to accommodate transportation scheduling.

Compatibility with Water Storage

The principal factors to evaluate are the thermal stresses generated when a canister is placed in the storage pool, the corrosion of the canisters, and the required water chemistry. An analysis of the thermally induced stresses will reveal any requirement for a controlled cooldown. By definition, the barrier canisters will not degrade appreciably by corrosion. However, the potential for rusting of the carbon steel canister will require water treatment. The use of a chromate-based water treatment has been shown to prevent significant rusting.

Compatibility with Air Storage

Air storage may cause rusting of a carbon steel canister. The presence of rust is undesirable because it will increase the chance that residual contamination on the canister will be spread in the storage and handling facilities. Although it has not been demonstrated, a radiation-damage resistant polymer coating may prevent rust. Higher ambient canister temperatures will be experienced in air storage. The maximum temperatures reached should not affect either the Inconel or carbon steel, but additional consideration must be given to the titanium if it will be held at temperatures approaching $400^{\circ} \mathrm{C}$ for a period of time. More information is needed on the influence of the alloy separation, observed in titanium grade 12 at $400^{\circ} \mathrm{C}$, on the corrosion resistance of that alloy.

TRANSPORTATION

A shipping cask for $H L W$ canisters will be designed to survive a wide range of accidents without release of radioactivity, as specified by government regulations ( 1 OCFR71 and $49 C F R 170$ to 199). The barrier canister is not necessarily required to survive these postulated accidents, although gross rupture should be precluded as a responsibility of good design. Both 
conventional processing canisters and barrier canisters must be protected by the shipping cask during transport to the repository. The principal difference is that the barrier canister must not be damaged during handling operations or during shipping such that its corrosion resistance is impaired.

The $2.5 \mathrm{~cm}$ thick carbon steel barrier canister will be immune to significant damage during routine handling. The Inconel canister is made of a very tough alloy and is $\sim 0.5 \mathrm{~cm}$ thick so it too should accommodate most routine handling scratches and impacts. The titanium designs are more vulnerable since they have the same $0.5 \mathrm{~cm}$ thick wall, but titanium toughness is significantly less than that of Inconel. The handling can only be addressed in detail within the context of a specific design for a waste vitrification cell, shipping cask, and receiving center. A facility designed with this concern in mind will reduce the probability of such damage occurring during normal operations.

REPOSITORY

Repository conditions impose the primary design requirements on barrier canisters. The potential repository geologies and the barrier canister designs recommended for study in these repositories are discussed in the Performance Criteria section.

Corrosion Resistance

Both titanium alloys and high nickel alloys are very corrosion resistant. However, the environment within a repository represents an unusual combination of pressure, temperature, radiation, and metal-rock contact in which long-term corrosion protection may be required. Exploring the synergistic effects of the repository parameters on material performance is one of the primary objectives of the Waste Package Program being carried out at PNL.

A barrier canister will be subjected to high temperatures as a result of the glass-filling process. A series of tests was carried out on specimens of titanium grades 2 and 12 and Inconel 625 to determine if the high process temperatures have any effect on the mechanical properties of these alloys. In addition, an accelerated corrosion test of a scoping nature was conducted on these heat treated specimens to determine any major changes in corrosion resistance. These tests and the results are described in the Appendix. The 
corrosion test was carried out in an oxygenated brine having the approximate composition of the WIPP "A" brine (Rockwell Hanford Operations 1980). The titanium alloys showed some reduction in corrosion rate as a result of the simulated process heat treatment, presumably as a result of building a thicker oxide layer. However, the titanium grade 2 specimens experienced severe corrosion pitting. This pitting is thought to be independent of the simulated process heat treatment and to be caused solely by the high oxygen content of the brine. The high oxygen content was used in this test to speed up corrosion even though it adds a degree of uncertainty because it is not typical of salt deposit brines. Pending further studies, titanium grade 2 is not recommended for use as a barrier canister. The titanium grade 12 corrosion appeared to increase when heat treated to $400^{\circ} \mathrm{C}$, but decreases if heat treated to $600^{\circ} \mathrm{C}$. Metallographic studies showed alloy component separation at $400^{\circ} \mathrm{C}$ and annealment at $600^{\circ} \mathrm{C}$, indicating there may be a correlation to the corrosion rates measured. However, the limited scoping studies have a large statistical uncertainty and the conclusions must be limited at this time to the observation that process heat will not dramatically affect the corrosion rate in the repository, and that severe corrosive pitting does not occur in an oxygenated brine.

The Inconel 625 specimens were subjected to two process heat treatments, one peaking at $600^{\circ} \mathrm{C}$ and the second at $1050^{\circ} \mathrm{C}$. The subsequent accelerated corrosion tests showed no effect from the $600^{\circ} \mathrm{C}$ process temperature and a higher apparent corrosion rate from the $1050^{\circ} \mathrm{C}$. However, the corrosion test was not conclusive because a scale was formed on the Inconel at $1050^{\circ} \mathrm{C}$ and this scale was measured as part of the corrosion loss. The conclusion is that Inconel 625 may corrode more rapidly as a result of the process heat, but the rate is still sufficiently low to ensure long-term barrier protection. No signs of corrosive pitting were observed.

Carbon steel is a candidate for the basalt, granite, and tuff repositories. No process heat treatments were conducted for this material since it is not proposed for the salt repository. For the purpose of this study, whose focus is processing and handling, it was assumed that other programs will be able to demonstrate that a canister of $\sim 2.5 \mathrm{~cm}$ wall thickness will be a longterm barrier. 


\section{Repository Pressure}

The forces on a canister in a repository can be a combination of hydrostatic head (uniform), lithostatic pressure (uniform), and uniaxial loads (such as shear, unrelieved rock stresses, or vertical overburden). Of these, the hydrostatic head is the only pressure loading anticipated in the first 1000 years in the granite, tuff, and basalt repositories, assuming that bentonite is not used as a backfill. The swelling of a bentonite backfill could impose an additional and even higher loading on the canister than the hydrostatic head. For the salt repository the creep of the salt is rapid enough to produce a lithostatic load on the canister within a 1000-year period of engineered barrier effectiveness.

The concept of the barrier canister requires the transfer of external loads to the glass, eliminating the need to make the canister walls thick enough to support the repository pressures. The questions to be resolved include canister behavior under a symmetric loading and the effect of small voids in the canister nozzle region.

Canister Retrieval

The ability to retrieve the canisters prior to the sealing of the repository is another design constraint. The assumptions are that an overcore technique can be used to remove the canisters in a salt repository and that the boreholes in granite, tuff, and basalt repositories will not have seized the canisters within the potential retrieval period of 150 years. However, assuming that canister removal is restricted in a hard-rock borehole, perhaps by loose rocks acting to jam the canister, it is recognized that the carbon steel canister could withstand the greatest abuse in a retrieval operation due to its thickness, followed in descending order of toughness and thickness by the Inconel and titanium canisters.

Repository Accidents

The accident analysis of a repository will examine several postulated handling accidents involving HLW canisters. The primary criterion for measuring accident severity is the quantity of respirable HLW glass fines released to the handling area. An associated concern is the prediction of damage to any of the facility engineered safeguards, which in this case will be the controlled ventilation boundary. The more massive the barrier canister or HLW 
canister with overpack, the less the chances any glass fines will be released. This consideration would favor the carbon steel design. Again, this point of evaluation is best carried out within the context of a specific design for a repository.

Effect of Canister Material on Glass Leaching

None of the proposed canister materials is predicted to accelerate glass leaching once the canister is finally breached. However, this possibility is under study in the ONWI Waste Package Program at PNL.

\section{Canister Material Attractiveness For Mining}

While Inconel and titanium are significantly more valuable than carbon steel, it does not appear that these would attract a mining operation simply because the depth of the repository and the low density of placement would make it uneconomical.

Quality Verification at Time of Emplacement

Assuming further analyses prove that barrier canister designs will meet the repository requirements, it will still be necessary to verify that the canister meets the design specifications and that the intermediate steps of glass-fill, interim storage, and transportation have not degraded the canister below these specifications. Further development work is required to determine if quality verification can be effectively carried out by process control and the conventional nondestructive evaluation (NDE) techniques such as $x-r a y$, ultrasonic, and eddy current inspections. 


\section{CONCLUSIONS AND RECOMMENDATIONS}

The concept of a processing canister that can ensure long-term separation protection of the HLW form against ground water in the repository should be seriously considered if engineered barriers are determined to be necessary for geologic disposal of HLW. A qualitative, step-by-step assessment of the canister's performance as it undergoes manufacture, glass-fill processing, interim storage, and transportation shows that canisters fabricated from corrosion-resistant metals such as titanium or high-nickel alloys are practical from the process viewpoint. The technology required is an extension of that already developed for conventional HLW processing canisters. The specific areas where a demonstration of remote processing capability is recommended as a research and development need are:

- filling the canister void with a load-bearing material such as stee 1 shot

- lid-closure welding in a remotely operated facility using GTA or upset-resistance techniques

- nondestructive evaluation of filled canisters for verification of canister integrity.

These research and development needs are in addition to the large program efforts such as the Waste Package Program, whose objectives are to qualify materials for various repository environments. While the alloys selected for this study are considered excellent candidates for barrier canisters, it was beyond the scope of this study to determine the actual corrosion allowances required for specific repository geologies where decay heat, radiation intensity, pressure, and ground-water composition are important parameters. In order to have a specific canister design for assessment purposes, a wall thickness was estimated. This required that corrosion allowances for titanium grade 12 and Inconel 625 were assumed to be smal1 $(<1 \mathrm{~mm})$ in comparison to the wall thickness ( 5 to $6 \mathrm{~mm}$ ) recommended for abrasion resistance, thermal stress at process temperature, and handling stress. In the case of a carbon stee 1 barrier canister, which may be suitable for nonsalt repositories, the process wall thickness requirement is only $6 \mathrm{~mm}$, but the corrosion allowance was assumed to be $\sim 20 \mathrm{~mm}$. 
The effect of process heat on the physical properties of titanium grade 2, titanium grade 12, and Inconel 625 was explored by conducting tensile and Charpy $V$-notch tests on specimens that had undergone temperature histories simulating the glass-filling processes. The titanium alloys (JHGM process only) appeared to undergo phase transformations that changed the physical properties by up to $20 \%$. There is some indication that these phase transformations are reversible by annealing. The Inconel 625 specimens were little affected by the $600^{\circ} \mathrm{C} \mathrm{JHGM}$ process temperature, but experienced a significant gain in toughness when heated to the $1050^{\circ} \mathrm{C}$ temperature of the ICM process.

These heat treated specimens were also exposed to an accelerated corrosion test using oxygenated brine. The titanium grade 12 and Inconel 625 specimens showed good corrosion resistance with measured values showing some effect of the heat treatment. The titanium alloys seemed to have a lower corrosion rate after being exposed to $600^{\circ} \mathrm{C}$, apparently due to a passivating oxide film. The Inconel 625 corrosion rate was not changed due to $600^{\circ} \mathrm{C}$ heat treatment and the corrosion rate for the $1050^{\circ} \mathrm{C}$ exposed sample was artificially high because of the test procedure.

The titanium grade 2 specimens showed severe corrosion pitting in the oxygenated brine. Pending further tests of this alloy in representative repository conditions, titanium grade 2 is not recommended as a barrier canister. 


\section{REFERENCES}

Baxter, R. G. 1981. Description of DWPF Reference Waste Form and Canister Long-Term Design Liaison: Waste Management Programs. DP-1606, E. I. duPont deNemours and Co., Savannah River Laboratory, Aiken, South Carolina.

Braithwaite, J. W., N. J. Magnani, and J. W. Munford. 1979. Titanium Al loy Corrosion in Nuclear Waste Environments. SAND79-2023C, Sandia Laboratories, ATbuquerque, New Mexico.

Cloninger, M. 0., C. R. Coles, and J. F. Washburn. 1980. An Analysis on the Use of Engineered Barriers for Geologic Isolation of Spent Fuel in a Reference Salt Site Repository. PNL 3356, Pacific Northwest Laboratory, Richland, Washington.

Cloninger, M. 0. and D. R. Coles. 1981. A Reference Analysis on the Use of Engineered Barriers for Isolation of Spent Nuclear Fuel in Granite and Basalt. PNL 3530, Pacific Northwest Laboratory, Richland, Washington.

Code of Federal Regulations, Title 10, Part 60. 1980. "Technical Criteria for Regulating Geologic High-Level Radioactive Waste." Federal Register, Vol. 45, No. 94, Tuesday, May 13, 1980. Advanced Notice of Rule Making.

Code of Federal Regulations, Title 10, Part 71. 1982. "Packaging of Radioactive Material for Transport and Transportation of Radioactive Material Under Certain Conditions."

Code of Federal Regulations, Title 40, Part 191. 1979. "Working Draft of Environmental Radiation Protection Standards for Management and Disposal of Spent Nuclear Fuel, High-Level and Transuranic Radioactive Waste."

Code of Federal Regulations, Title 49, Parts 170 to 199. 1982. (Department of Transportation Regulations governing the transport of hazardous materials).

Moore, E. L. 1978. Commercial Waste Packaging Studies Task 02, High-Level Waste Package Acceptance Criteria Study. RHO-ST-10, Rockwell Hanford Co., Richland, Washington.

Nesbitt, J. F., S. C. ST ate, and L. K. Fetrow. 1980. Decontamination of High-Level Waste Canisters. PNL-3514, Pacific Northwest Laboratory, Richland, Washington.

Nuclear Services Corporation. 1978. Recommendations for Code and Standards to be Used for Design and Fabrication of High Level Waste Canister. NSC1-78-004 by Nuclear Services Corporation for Rockwell Hanford Operations (Rockwell Report RH0-C-13), Campbe11, California.

Office of Nuclear Waste Isolation (ONWI). 1980. NWTS Program Criteria For Geologic Disposal of Nuclear Waste, Waste Package Functional Criteria. ONWI-33(4), Office of Nuclear Waste Management, Columbus, Ohio. 
Pitman, S. G., B. Griggs, and R. P. Elmore. 1980. "Evaluation of Metallic Materials for Use in Engineered Barrier Systems." In Scientific Basis for Nuclear Waste Management, Vol. 3, p. 523. Plenum Press, New York.

Pitman, S. G. 1981. Investigation of Susceptibility of Titanium-Grade 2 and Titanium-Grade 12 to Environmental Cracking in a Simulated Basalt Repository Environment. PNL-3915, Pacific Northwest Laboratory, Richland, Washington.

Raines, G. I., L. D. Rickertsen, H. C. Claiborne, J. L. McElroy and R. W. Lynch. 1980. "Development of Reference Conditions for Geologic Repositories for Nuclear Waste in the U.S.A." Paper presented at The Third International Symposium on the Scientific Basis for Nuclear Waste Management. Held as part of the Materials Research Society Annual Meeting, Boston, Massachusetts.

Rockwell Hanford Operations (RH0). 1980. Engineering Order RSD-BWI-DP-007, July 11, 1980. Richland, Washington.

Simonen, F. A. and S. C. Slate. 1979. Stress Analysis of High-Level Waste Canisters: Methods, Applications, and Design Data. PNL-3036, Pacific Northwest Laboratory, Richland, Washington.

Slate, S. C., W. A. Ross and W. L. Partain. 1981. Reference Commercial HighLevel Waste Glass and Canister Definition. PNL-3838, Pacific Northwest Laboratory, Richland, Washington.

Westerman, R. E. 1980. Investigation of Metallic, Ceramic, and Polymeric Materials for Engineered Barrier Applications in Nuclear-Waste Packages. PNL-3484, Pacific Northwest Laboratory, Richland, Washington.

Westinghouse Electric Corp. 1980. Engineered Waste Package System Design Specification. AESD-TME-3055, Westinghouse Electric Corp., Pittsburgh, Pennsylvania.

U. S. Department of Energy (DOE). 1980. Final Environmental Impact Statement: Management of Commercially Generated Radioactive Waste. DOE/EIS0046F, Washington, D. C. 
APPENDIX

MATER IAL EVALUATIONS 
APPENDIX

MATERIAL EVALUATIONS

A barrier canister for long-term storage of nuclear wastes must resist corrosion, deformation, and fracture in three environments: 1) hightemperature air, 2) molten glass experienced while the canisters are filled with glass, and 3) hydrothermal ground waters to which the canisters may be exposed in the repository. The canisters are to be filled either by glass pouring, which will produce canister temperatures up to $600^{\circ} \mathrm{C}$, or by in-can melting, in which the canisters are heated to $1050^{\circ} \mathrm{C}$. Canisters in the repositories may experience temperatures up to $150^{\circ} \mathrm{C}$ for defense $H L W$ and $250^{\circ} \mathrm{C}$ for commercial HLW.

Barrier systems proposed to date use at least two structural elements to accomplish the glass-filling and long-term storage functions. A stainless steel canister provides adequate strength and oxidation resistance during glass filling, but is not considered as a barrier to releases in disposal, especially brine, environments. A cast iron, mild steel, Inconel, or titanium overpack provides sufficient corrosion resistance to serve as a barrier to ground-water contact with the HLW glass for periods of 100 to 1000 years. This study is concerned with determining the feasibility of using a single canister for both the filling and storage functions. The purpose of this testing program is to make a preliminary evaluation of the effects of hightemperature thermal cycles, simulating the thermal cycles associated with the candidate glass-filling operations, on the materials' corrosion resistance to hydrothermal brine. A severely corrosive (proof-test) environment (oxygenated brine, which is atypical of actual repository brines) was chosen for this exposure because satisfactory material performance in this environment should indicate that such materials could be used in less aggressive environments.

Contained in this chapter are descriptions of the materials used in this study, the methods used to evaluate these materials, results of the experimental program, and conclusions pertinent to the use of these materials for fabrication into barrier canisters. 
Three materials were used in this investigation: titanium grade 2, titanium grade 12, and Inconel 625. The titanium grades were evaluated in the as-received condition and after the JHGM-simulating heat treatments at $400^{\circ} \mathrm{C}$ and $600^{\circ} \mathrm{C}$. Inconel 625 was evaluated in the as-received condition and after heat treatments at 600 (simulating the $\mathrm{JHGM}$ ) and $1050^{\circ} \mathrm{C}$ (simulating the ICM). The purpose of the three heat treatments was to simulate the aging reactions that occur in canister materials due to the glass-filling process. These aging reactions can potentially degrade the performance of materials, so the testing was designed to specifically look for property degradation. The materials used for this study were chosen on the basis of previous experience, performance in barrier corrosion tests in brine (Pitman, Griggs, and Elmore 1980), and enviromechanical testing in other media (Pitman 1981). All of the materials were received in the mill-annealed condition; i.e., titanium alloys were held at $760^{\circ} \mathrm{C}$ for 30 minutes and then air cooled, and Inconel 625 was held at $980^{\circ} \mathrm{C}$ for 15 minutes and then cooled in a protective atmosphere.

Titanium grade 2 is an intermediate strength, commercial purity grade. It has excellent corrosion resistance in aqueous environments at temperatures less than $200^{\circ} \mathrm{C}$, but breakdown of the passivating film causes it to become increasingly susceptible to localized corrosion at higher temperatures. It is not known to be susceptible to stress corrosion cracking in aqueous media.

Titanium grade 12 contains, nominally, $0.8 \% \mathrm{Ni}$ and $0.3 \%$ Mo. It was developed for increased resistance to crevice corrosion and pitting at high temperatures, particularly in the high chloride ion environments which would otherwise be damaging to the integrity of passivating films. The strength of titanium grade 12 is slightly higher than that of grade 2, but it is only about one-third as tough (Westerman 1980).

Inconel 625 (nominally $60 \% \mathrm{Ni}, 20 \% \mathrm{Cr}, 10 \% \mathrm{Mo}, 5 \% \mathrm{Fe}, 4 \% \mathrm{Nb}, 1 \% \mathrm{Co}$, plus trace elements) has high strength, toughness, and corrosion resistance. It is often used for applications requiring good mechanical and enviromechanical properties at high temperatures. 
MECHANICAL AND CORROSION TEST PROCEDURES

The experimental program was designed to evaluate the effects of the canister filling process and exposure to hot brine on the structural integrity of the canister materials. The effects of the filling process on the mechanical properties of the candidate materials were evaluated using tensile tests and Charpy $V$-notch impact tests before and after the materials were exposed to temperatures representative of those expected during filling. U-bend and tensile specimens that were exposed to representative thermal cycles were then given an exposure to Waste Isolation Pilot Project (WIPP) Brine A (Rockwell Hanford Operations 1980 ) at $150^{\circ} \mathrm{C}$ to evaluate the effects of this severely corrosive environment on the materials.

Two heat treatments were used to bracket thermal exposures expected from the JHGM process: 1) a 3 hour heatup to $400^{\circ} \mathrm{C}, 1$ hour hold, and cooldown at $20^{\circ} \mathrm{C} / \mathrm{h}$; and 2) a rapid heatup to $600^{\circ} \mathrm{C}, 20$ hour hold, and cooldown at $10^{\circ} \mathrm{C} / \mathrm{h}$. The heat treatment used to approximate conditions expected for the ICM process consisted of heating the specimens rapidly to $1050^{\circ} \mathrm{C}$, holding for 20 hours, cooling to $600^{\circ} \mathrm{C}$ in 2 hours, and slow cooling to ambient at $20^{\circ} \mathrm{C} / \mathrm{h}$. Millannealed specimens were included as a basis for comparison in mechanical and corrosion tests. The specimens were weighed before and after heat treating.

Mechanical properties of the candidate canister materials were evaluated using tensile tests and Charpy impact tests. Tensile tests were run at a crosshead rate of $0.02 \mathrm{in./min}$. Load and displacement were recorded so the yield and tensile strengths could be determined. Elongation and reduction of the area were determined by measuring the fractured specimens. Charpy impact tests were done using a pendulum-type, instrumented impact machine. Load and displacement versus time were recorded using a microprocessor-based data acquisition system so that characteristics of the fracture process could be noted and dynamic yield strength and energy to fracture could be found.

Corrosion tests were done in an Inconel autoclave using WIPP Brine A that had been saturated with oxygen at room temperature and pressure. The corrosion specimens were bent and placed, without being allowed to spring back, into channels made of Inconel 625 for the Inconel 625 specimens and titanium grade 2 for the titanium alloy specimens. The specimens were exposed for 166 days at $150^{\circ} \mathrm{C}$. About $1 \&$ of oxygen-saturated brine was added each day to replenish any elements which were depleted during the corrosion process. After 
the exposure the specimens were ultrasonically cleaned in high-purity water, bent to remove some scale, abraded mechanically until free of scale, rinsed in acetone, dried, and weighed. The U-bend channels are shown in Figure A.1.

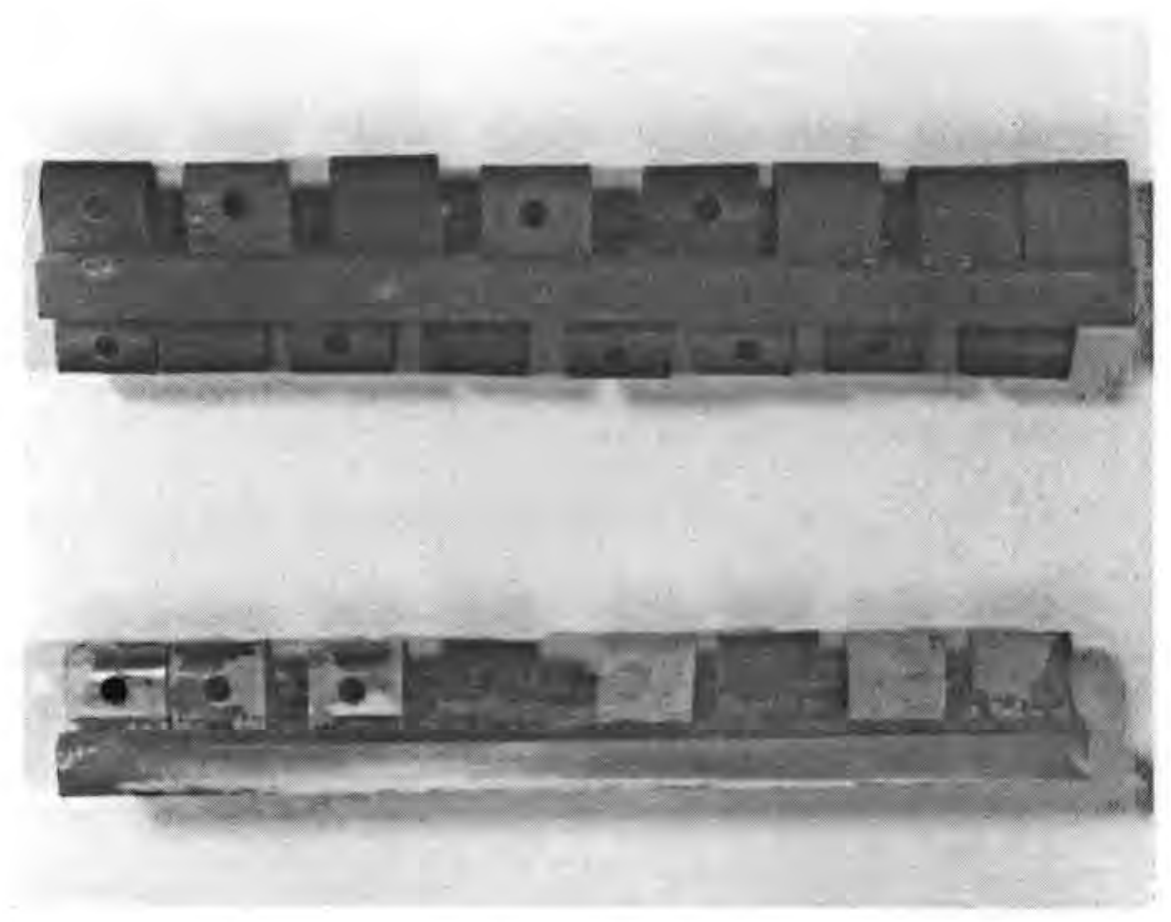

FIGURE A.1. U-Bend Specimens Used in Corrosion Tests (seen after exposure in brine for 166 days $0150^{\circ} \mathrm{C}$ )

These corrosion tests must be considered accelerated tests for three reasons: 1) inundation with brine at such a high temperature is unlikely, 2) constant replenishment of brine solution could occur only if ground water flows through the repository (a highly unlikely condition) and 3) the oxygen content of the inlet solution was $32 \mathrm{ppm}$, many times higher than would be expected in an inundated repository.

A high oxygen content is particularly severe for localized corrosion, potentially the most damaging form of corrosion. Because of the severe nature of these tests, the weight change data is not intended to apply directly to lifetime predictions. These tests are of a preliminary nature and are intended to discover inherent weaknesses in the materials and potential susceptibility to degradation by the processing techniques under consideration. 
RESULTS OF TESTS

Charpy impact tests were used to evaluate the effects of material aging reactions induced by thermal exposures on the proposed canister materials. Tensile tests, corrosion tests, fractography, and metallography were used to evaluate the effects of thermal exposure and subsequent exposure to brine on the materials. The results obtained from each test method are presented in the next three sections, and implications for canister processing and structural integrity during storage are described.

Impact Tests

The results of Charpy V-notch impact tests are given in Table A.1. The energy absorbed by the specimen during fracture and the lower-bound yield strength are given. The energy absorbed is a good indication of the resistance of the material to fracture under severe loading conditions. Dynamic yield strength can be used to determine the significance of metallurgical change in the test material.

TABLE A.1. Results of Charpy Impact Tests (Values shown are the averages of two tests)

\section{Titanium Grade 2}

Heat Treatment

Mill Annealed $400^{\circ} \mathrm{C}$ Thermal Cycle $600^{\circ} \mathrm{C}$ Thermal Cycle

Dynamic Yield Strength, ksi Energy Absorbed, ft-1b

Energy Absorbed, ft-1b

\begin{abstract}
Dynamic Yield Strength, ksi
\end{abstract}
Energy Absorbed, ft-1b

Energy Absorbed, ft-1b

(n)

Dynamic Yield Strength, ksi

Energy Absorbed, ft-1b

84.8

87.8

39.6

33.6

42.3

Titanium Grade 12

Heat Treatment

$\frac{\text { Mill Annealed }}{99.5} \frac{400^{\circ} \mathrm{C} \text { Thermal Cycle }}{91.7} \frac{600^{\circ} \mathrm{C} \text { Thermal Cycle }}{89.0}$

$\begin{array}{lll}8.8 & 8.1 & 7.82\end{array}$

Incone 1625

Heat Treatment

Mill Annealed $400^{\circ} \mathrm{C}$ Thermal Cycle $600^{\circ} \mathrm{C}$ Thermal Cycle

113.4

85.1
117.1

76.2
77.3

120.5 
The impact toughness of titanium grade 2 was significantly decreased by aging at $400^{\circ} \mathrm{C}$, but was increased slightly after the $600^{\circ} \mathrm{C}$ exposure. The dynamic yield strength of the material was not significantly affected. Diffusion calculations indicated that there was not enough time for oxygen to enter deeply into the material to cause this ductility decrease by oxygen embrittlement. The cause of the decrease was not determined.

Titanium grade 12 exhibited a slight decrease in dynamic yield strength and toughness after the 400 and $600^{\circ} \mathrm{C}$ thermal cycles. This mechanical performance is not in itself alarming, but the fracture surfaces showed an unusual appearance. The material normally fractures with small, evenly spaced microvoids, but those specimens aged at $400^{\circ} \mathrm{C}$ had fracture surfaces with large, deep voids. Upon visual inspection using low magnification, the Charpy fracture surfaces seemed to contain large, spherical precipitates.

The fracture surfaces of titanium grade 12 were examined using a scanning electron microscope to determine the cause of the toughness loss. The fracture occurred throughout the specimens by the process of microvoid coalescence; there is no evidence of transgranular fracture. There is evidence that a second phase formed at the grain boundaries during the aging process. The composition of this phase was studied using energy-dispersive spectroscopy. It was found to contain impurities such as iron and silicon as well as relatively high amounts of nickel. The detectable amounts of iron and silicon may be present due to the migration of impurities to grain boundaries at elevated temperatures. The presence of abnormally high amounts of nickel, as well as the appearance of a distinct second phase, support the conclusion that a titanium-nickel intermetallic phase formed at the grain boundaries during heat treatment. An example of the fracture surface appearance is shown in Figure A.2. 


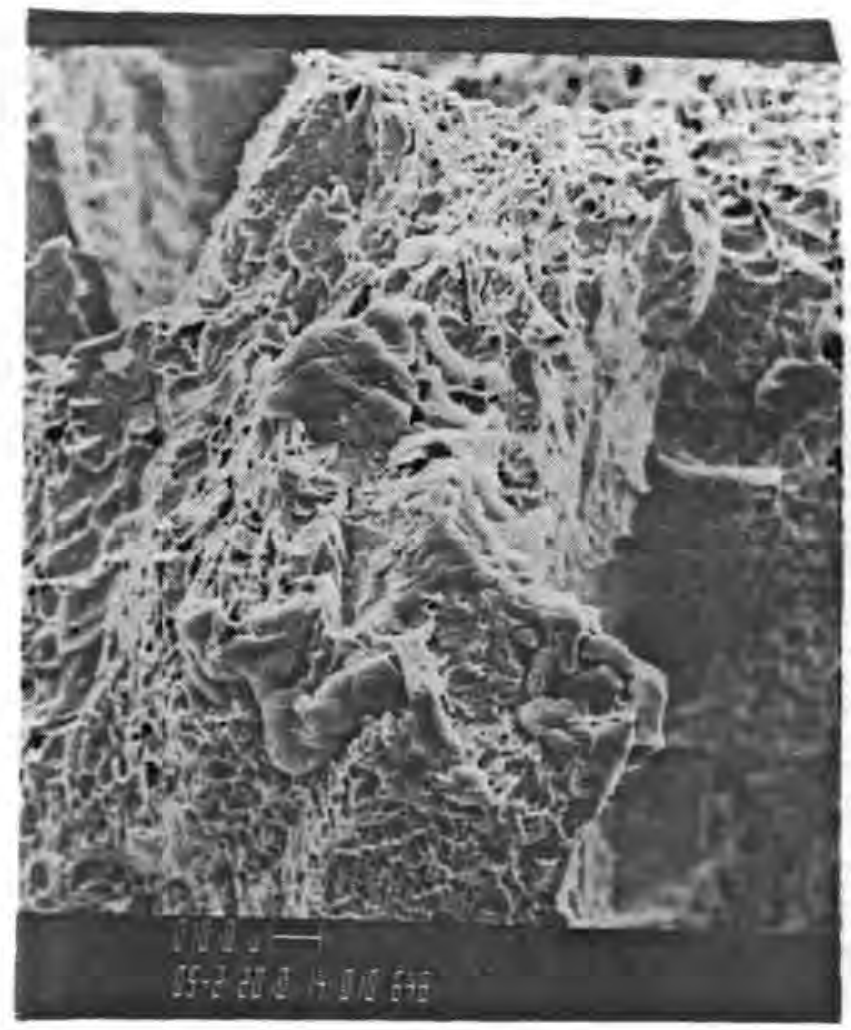

FIGURE A.2. Fracture Surface of Titanium Grade 12 Charpy Impact Specimen Showing Appearance of a Second Phase in the Material

Inconel 625 seems to harden after aging at $600^{\circ} \mathrm{C}$, and to soften at $1050^{\circ} \mathrm{C}$. Toughness of the material aged at $1050^{\circ} \mathrm{C}$ is almost $50 \%$ greater than the original material, and dynamic yield strength is about $50 \% 1$ ower.

\section{Tensile Tests}

The results of tensile tests are given in Table A.2. Titanium grade 2 was affected by the thermal cycles in several ways. Its ultimate strength decreased significantly after aging at $400^{\circ} \mathrm{C}$, but yield strength was hardly affected. Elongation increased slightly, but reduction of area increased significantly. The yield and ultimate strengths were not further affected by other exposures. Elongation was greater at $600^{\circ} \mathrm{C}$ than at $400^{\circ} \mathrm{C}$, but reduction of area was lower. When specimens aged at $600^{\circ} \mathrm{C}$ were exposed to a brine solution for 166 days at $150^{\circ} \mathrm{C}$, pitting occurred along the cut edges of the specimens. The ductility of these specimens was significantly lowered by the brine exposure. Fracture occurred between pits, and the fracture surfaces lacked the surface relief normally found in fractures of this material. 
TABLE A.2. Results of Tensile Tests

(Values shown are the average of two tests)

Titanium Grade 2

Heat Treatment and Exposure

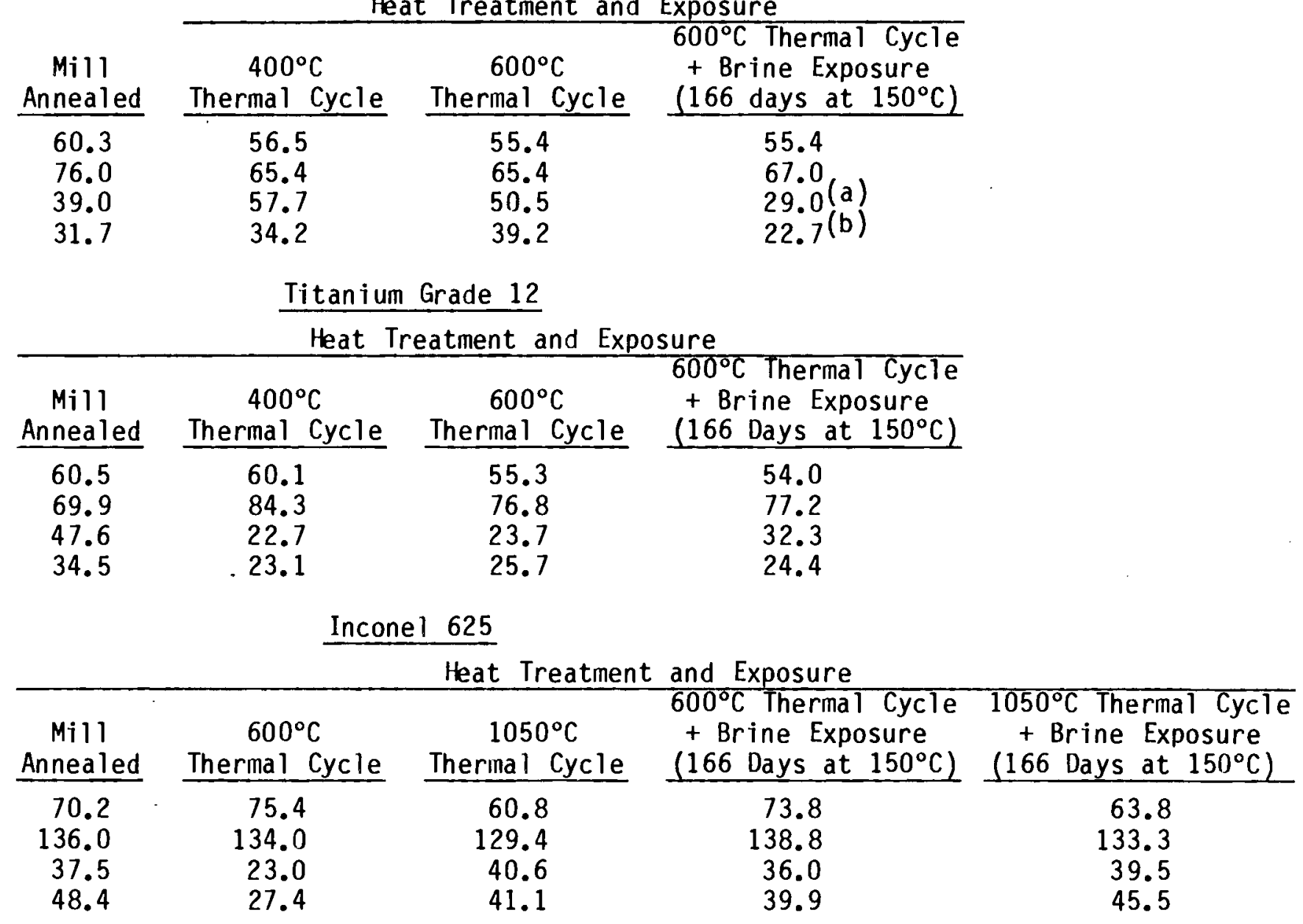

Yield Strength, ksi

Ultimate Tensile Strength, ksi

Reduction of Area, \%

El ongation in 1-in. Gauge, \%

Yield Strength, ksi

Ultimate Tensile Strength, ksi

Reduction of Area, \%

Elongation in 1-in. Gauge, $\%$

Yield Strength, ksi

Ultimate Tensile Strength, ksi

Reduction of Area, \%

Elongation in 1-in. Gauge, \%

(a) Average of $39.4 \%$ from non-pitted specimen and $18.6 \%$ from pitted specimen.

(b) Average of $26.6 \%$ from non-pitted specimen and $18.8 \%$ from pitted specimen. 
The ultimate tensile strength of titanium grade 12 increased slightly after aging at $400^{\circ} \mathrm{C}$, but the yield strength did not change significantly. Ductility was significantly lower after aging at $400^{\circ} \mathrm{C}$. Similar results were found in specimens aged at $600^{\circ} \mathrm{C}$. In contrast to titanium grade 2 , the specimens of titanium grade 12 seemed unaffected by exposure to brine.

The yield strength of Inconel.625 increased after aging at $600^{\circ} \mathrm{C}$, but decreased after aging at $1050^{\circ} \mathrm{C}$. This decrease of yield strength corresponds to an increase in ductility. This is consistent with the results of the Charpy impact tests, where a large increase of toughness was found when specimens were aged at $1050^{\circ} \mathrm{C}$.

The Inconel tensile specimens were not adversely affected by exposure to brine. The specimens aged at $600^{\circ} \mathrm{C}$ and subsequently exposed to brine had an increased toughness relative to specimens similarly aged but not exposed.

Corrosion Tests

Results of the corrosion tests in brine, using mill-annealed specimens and heat treated specimens, are shown in Table A.3. The corrosion rate of titanium grade 2 was significantly reduced by prior heat treatment. The oxide which formed during thermal cycling in air was apparently responsible for passivating the surfaces. The corrosion rate of titanium grade 12 was highest after the $400^{\circ} \mathrm{C}$ heat treatment. This indicates that the material is sensitized by passing through a critical temperature range, and that this sensitization is responsible for an increased corrosion rate. The specimens aged at $600^{\circ} \mathrm{C}$ may also be sensitized, to a lesser extent, because they passed through this range on cooling. This may account for the higher corrosion rates of titanium grade 12 relative to grade 2 after the $600^{\circ} \mathrm{C}$ thermal cycle, even though both samples showed a significant drop in corrosion rate as compared to the samples that had been heat treated at $400^{\circ} \mathrm{C}$. The decrease of toughness in Charpy tests, decrease of ductility in tensile tests, and increase in corrosion rate may all be attributable to the formation of a titanium-nickel intermetallic phase during the thermal cycle. 
TABLE A.3. Results of Corrosion Tests in Brine $\left(\mathrm{mg} / \mathrm{dm}^{2} \mathrm{yr}\right)(\mathrm{a})$

\begin{tabular}{lccc}
\multicolumn{4}{c}{ Heat Treatment } \\
\hline Mill (b) & $400^{\circ} \mathrm{C}(\mathrm{c})$ & $600^{\circ} \mathrm{C}(\mathrm{c})$ & $1050^{\circ} \mathrm{C}(\mathrm{c})$ \\
Annealed & Thermal Cycle & Thermal Cycle & Thermal Cycle \\
\cline { 2 - 4 }
\end{tabular}

Titanium Grade 2 32.8

21.1

3.5

Titanium Grade 12

21.3

29.0

16.7

Inconel 625

13.9

13.0

$360.8^{(d)}$

(a) Large differences in weight change were found between similar specimens,

(b) Average of four measurements.

(c) Average of two measurements.

(d) This includes weight lost due to oxidation during the heat treatment simulating the ICM process.

The results of these tests may be compared to those of other researchers; however, the value of direct comparison is limited because the methods of exposure and cleaning vary widely and these methods can have an apparent effect on the measured corrosion rates. The effect of high oxygen content on corrosion rate is evident by comparing data from the current study to that of Westerman's (1980). Corrosion rates are about five times higher in the current study where high oxygen content is present than in Westerman's studies made at low oxygen levels and higher solution temperature $\left(250^{\circ} \mathrm{C}\right)$. These increased rates are still small relative to the canister thickness. At Sandia Laboratory, Braithwaite, Magnani and Munford (1979) measured corrosion rates of titanium grade 12. Their results are within a factor of 2 or 3 of the current study.

The highest corrosion rates measured in weight-gain tests of titanium correspond to about $1 \mu \mathrm{m} / \mathrm{yr}$, indicating that a canister wall thickness satisfactory for structural purposes would be adequate for resistance to general corrosion. This is in concurrence with the studies mentioned previously. It should be emphasized that the extrapolation of corrosion rates measured in necessarily short laboratory tests to very long time periods involves complexities which cannot be resolved in a scoping test of this nature.

None of the stressed corrosion specimens showed any sign of pitting or cracking; however, the titanium grade 2 tensile specimens were badly pitted. Signs of cracking were apparent after the tensile tests. It is not known 
whether these cracks formed during the exposure and opened up during the tensile tests or formed as the tensile specimens were loaded. An example of surface pitting and associated cracking is shown in Figure A.3. The fracture surfaces of the tensile specimens had shallower dimples than the unexposed specimens, but the dimples did not seem to be initiated by a second phase in the material. Metallographic analysis was done to determine the cause of ductility loss experienced by titanium grade 2 in brine. The presence of hydrides was specifically investigated, as it was suspected that hydrogen formed during pitting had entered the material and caused the formation of hydrides. As can be seen in Figure A.4, the hydrogen content of the exposed material is not abnormally high. This section was taken from an area near the fracture of a badly pitted tensile specimen. Hydrides in this material appear as needlelike particles and are usually located at the grain boundaries. The clumps of black particles are retained beta phase, stabilized by iron. Smaller dark areas are probably etch pits, inevitable artifacts of the metallographic procedure. Therefore, loss of ductility was probably not due to hydride embrittlement, but may have been due to stress concentration at corrosion pits.

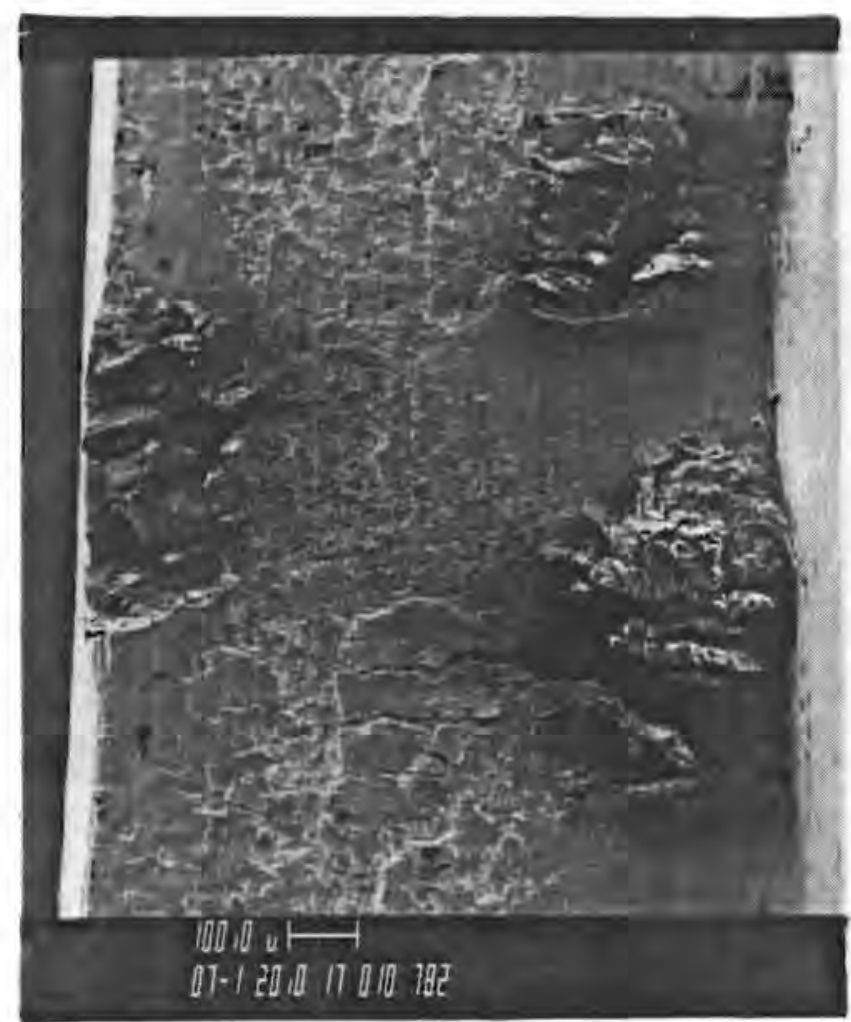

FIGURE A.3. Surface Pitting and Associated Cracking from Titanium Grade 2 Tensile Specimen 


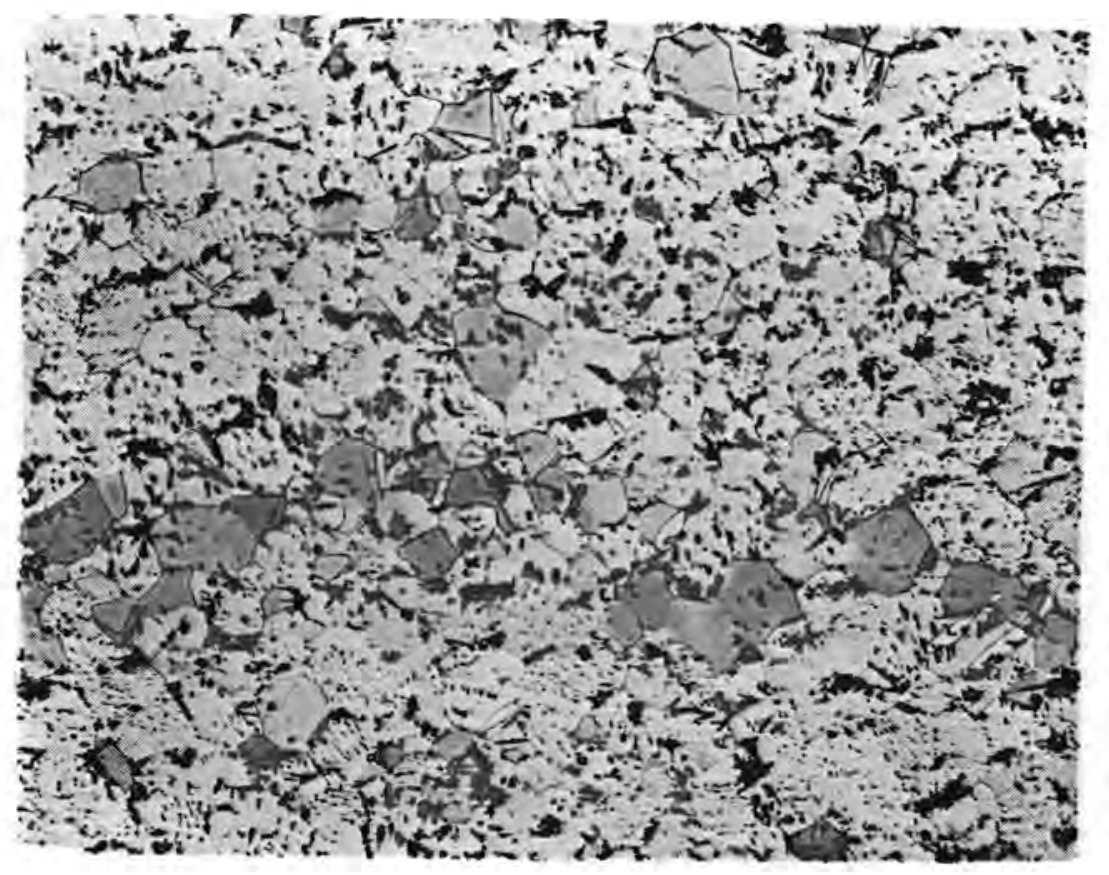

FIGURE A.4. Metallography of Titanium Grade 2 from Specimen Exposed to $600^{\circ} \mathrm{C}$ Thermal Cycle and to Brine

The U-bend fixture was fabricated from titanium grade 2 plate. This fixture was not expected to be a test specimen; however, severe pitting occurred on both pickled and machined surfaces of the plate. Corrosion also occurred in a crevice where one of the specimens was held. The largest pits are shown in Figure A.5. It is clear from the severity of the pits that formed in a relatively short test that the material may not be suitable for use in this environment. It should be kept in mind, though, that the oxygenated brine used in this test greatly accelerates titanium grade 2 corrosion relative to the environment which may be expected in a salt repository. 


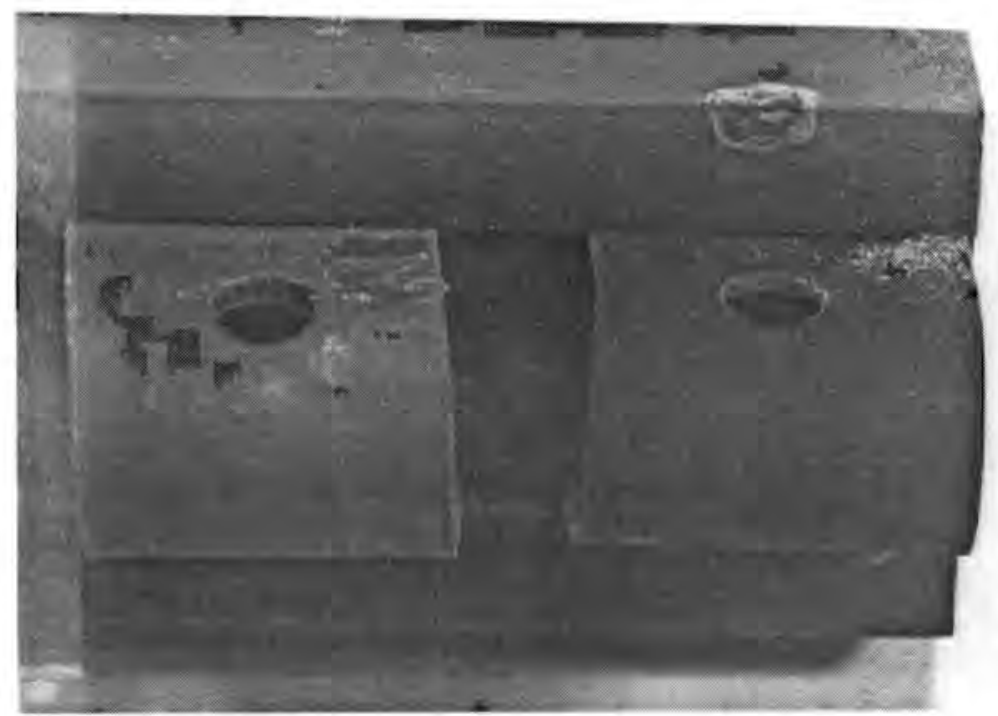

FIGURE A.5. Largest Pits Found On Titanium Grade 2 Fixture (Specimens are 1-in. wide.)

The corrosion rate of Inconel 625 is unaffected by aging at $600^{\circ} \mathrm{C}$; however, the apparent weight loss of specimens aged at $1050^{\circ} \mathrm{C}$ was about 20 times as high as that of mill-annealed specimens. This can be explained by the loss of scale (which was formed at $1050^{\circ} \mathrm{C}$ ) as the specimens were bent into fixtures, as they were released from the fixtures, and during the exposure. The appearance of these specimens with the scale removed was similar to those specimens aged at $600^{\circ} \mathrm{C}$. There were no signs of pitting or cracking. The relatively high weight loss is not necessarily a cause for alarm as long as canister thickness is increased accordingly; however, future tests should be done to determine the corrosion rates when the scale is removed prior to exposure. 
,

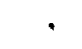




\section{MATER IALS CONCLUSIONS}

The results of this experimental program can be used to draw conclusions regarding the effects of process cycles on the suitability of titanium grades 2 and 12 and Inconel 625 for use as barrier canisters:

1. Titanium grade 2 is susceptible to pitting in oxygenated WIPP Brine A at $150^{\circ} \mathrm{C}$. Although the extent of this susceptibility cannot be determined from the accelerated tests performed here, the use of this material cannot be recommended for long-term storage.

2. Titanium grade 12 undergoes some form of sensitization when the material is given the $400^{\circ} \mathrm{C}$ thermal cycle representative of the glass pouring process. Characteristics of the fracture process are altered, and corrosion rates are increased significantly. Some reduction would occur if the sensitization process were reversed by heating the canister and allowing it to cool more rapidly. The corrosion rate of both titanium grades is reduced, relative to as-received material, when they have been heat treated at $600^{\circ} \mathrm{C}$, indicating the formation of a thicker oxide coating has provided additional corrosion protection. The corrosion rate of titanium grade 12 after the $600^{\circ} \mathrm{C}$ thermal cycle is higher than that of grade 2. This suggests that the material is partially sensitized by slow cooling in the sensitization temperature range.

3. Inconel 625 shows no adverse effects from aging at $600^{\circ} \mathrm{C}$ and has a low corrosion rate in brine. It appears suitable as a canister material for this application.

4. Inconel 625 forms a thick, loose scale when exposed to the $1050^{\circ} \mathrm{C}$ thermal. cycle. Allowance should be made for loss of this material, and corrosion rates need to be evaluated with the scale removed.

5. Mechanical properties were significantly affected in almost all cases. However, the changes should not have an appreciable impact on the design of barrier canisters. All designs have large factors of safety regarding stress levels, so the relatively small changes can be easily accommodated. 

No. of

Copies

\section{OFFSITE}

27 DOE Technical Information Center

R. E. Cunningham

Office of Nuclear Safety

Materials and Safeguards

Room 562

Nuclear Regulatory Commission

7915 Eastern Avenue

Silver Springs, MD 20910

2 Division of Waste Management

Nuclear Regulatory Commission

Washington, DC 20555

ATTN: J. B. Martin

R. Dale Smith

Materials Section Leader

High-Level Waste Licensing Branch

Nuclear Regulatory Commission

Washington, DC 20555

W. E. Mott

DOE Division of Environmental Control Technology

Washington, DC 20545

9 DOE Terminal Waste Disposal and Remedial Action

NE30, GTN

Washington, DC 20545

ATTN: W. W. Ballard

F. Coffman

C. R. Cooley

C. H. George

K. Laughon

M. J. Lawrence

J. A. Leary

A. F. Perge

R. W. Ramsey, Jr.
No. of

Copies

6 DOE Office of Defense Waste and By-Products Management

DP-12, GTN

Washington, DC 20545

ATTN: G. H. Daly

J. E. Dieckhoner

D. J. McGoff

G. Oertel

A. L. Taboas

R. D. Walton

W. F. Holcomb

National Institutes of Health

Bldg. 21, Radiation Safety

Branch

Bethesda, MD 20205

S. A. Mann

DOE Chicago Operations and Region Office

Argonne, IL 60439

J. Neff

Department of Energy

Columbus Program Office

505 King Avenue

Columbus, $\mathrm{OH} 43201$

2 DOE Idaho Operations Office

550 2nd Street

Idaho Falls, ID 83401

ATTN: J. P. Hamrick

J. B. Whitsett

Office of the Assistant Mgr. for Energy Research \& Development DOE Oak Ridge Operations Office P. 0. Box E

Oak Ridge, TN 37830

4 Oak Ridge National Laboratory

P. 0. Box $Y$

Oak Ridge, TN 37830

ATTN: R. E. Blanco

J. 0. Bl omeke

D. E. Ferguson

L. Mezga 
No. of

Copies

Los Alamos Scientific Laboratory

P. 0. Box 1663

Los Alamos, NM 87544

3 DOE Savannah River Operations Office

P. 0. Box A

Aiken, SC 29801

ATTN: E. S. Goldberg

T. B. Hindman

R. P. Whitfield

3 Exxon Nuclear Idaho

P. 0. Box 2800

Idaho Falls, ID 83401

ATTN: D. L. Condotta

R. A. Brown

File Copy

2 EG\&G Idaho

P. 0. Box 1625

Idaho Falls, ID 83415

ATTN: G. B. Levin

R. L. Tallman

S. G. Harbinson

DOE San Francisco Operations

1333 Broadway

Oakl and, CA 94612

R. Y. Lowrey

DOE AIbuquerque Operations Office

P. 0. Box 5400

Albuquerque, NM 87185

2 Allied-General Nuclear Services

P. 0. Box 847

Barnwell, SC 29812

ATTN: J. A. Buckham

A. Williams

2 Argonne National Laboratory

9700 South Cass Avenue

Argonne, IL 60439

ATTN: J. H. Kittel

M. J. Steindler/L. E. Trevorrow
No. of

Copies

11 Battelle Memorial Institute

Office of Nuclear Waste

Isolation

505 King Avenue

Columbus, $\mathrm{OH} 43201$

ATTN: S. H. Basham

A. Brandstetter

W. Carbiener

J. Carr

N. E. Carter

J. 0. Duguid

S. Goldsmith

P. L. Ho fmann

M. Kehnemuy $i$

J. F. Kircher

Beverly Rawles

2 Rockwell International

Rocky flats Plant

P. 0. Box 464

Golden, CO 80401

ATTN : W. S. Bennett

E. Vejvoda

A. B. Martin

Rockwell International

8900 DeSoto Avenue

Canoga Park, CA 91304

8 E. I. duPont deNemours \& Company Savannah River Laboratory

Aiken, SC 29801

ATTN: W. H. Baker

J. L. Crandall

D. Witt

D. E. Gordon

A. S. Jennings

D. L. McIntosh

S. Mirshak

S. W. O'Rear

R. Maher

E. I. duPont deNemours \& Company Savannah River Plant Aiken, SC 29801 
No. of

Copies

R. Williams

Electric Power Research

Institute

3412 Hillview Avenue

P. 0. Box 10412

Palo Alto, CA 94304

Environmental Protection Agency

Technological Assessment

Division (AW-559)

Office of Radiation Programs

U.S. Environmental Protection Agency

Washington, DC 20460

R. G. Barnes

General Electric Company

175 Curtner Avenue

(M/C 160)

San Jose, CA 95125

L. H. Brooks

Gulf Energy and Environmental Systems

P. 0. Box 81608

San Diego, CA 92138

R. K. Brown

Westinghouse Electric Corp.

Advanced Energy Systems Div.

WIPP Library

P. 0. Box 40039

Albuquerque, NM 87196

J. P. Duckworth, Plant Manager

Nuclear Fuels Services, Inc.

P. 0. Box 124

West Valley, NY 14171

L. J. Jardine

Bechtel National, Inc.

Box 3965

San Francisco, CA 94119
No. of

Copies

J. L. Larocca, Chairman

Energy Research and Development Authority

Empire State Plaza

Al bany, NY 12223

2 Lawrence Livermore Laboratory

P. 0. Box 808

Livermore, CA 94550

ATTN: J. H. Campbell

W. G. Sutcliff

5 Sandia Laboratories

Albuquerque, NM 87185

ATTN: D. R. Anderson

O. E. Jones

R. G. Kepler

M. Molecke

W. Weart

J. W. Bartlett

The Analytic Sciences Corp.

6 Jacob Way

Reading, MA 01867

W. A. Freeby

Bechtel Group, Inc.

Fifty Beale Street

P. 0. Box 3965

San Francisco, CA 94119

J. R. Potter

Chem-Nuclear Systems, Inc.

P. 0. Box 1866

Bellevue, WA 98009

R. G. Post

College of Engineering

University of Arizona

Tucson, AZ 85721

L. L. Hench

Department of Materials Science and Engineering

University of Florida

Gainesville, FL 32611 
No. of

Copies

w. Tope

Westinghouse Electric Corp.

Mail Stop 23

Box 3912

Pittsburgh, PA 15230

R. Roy

202 Materials Research Laboratory

University Park, PA 16802

F. K. Pittman

3508 Sagecrest Terrace

Ft. Worth, TX 76109

D. Newby

Advanced Energy Systems Division

P. 0. Box 10864

Pittsburg, PA 15236

\section{ONSITE}

8 DOE Richland Operations Office

E. A. Bracken

P. A. Craig

0. J. Elgert

R. D. Izatt

H. E. Ransom

J. J. Schreiber

M. W. Shupe

J. D. White

12 Rockwell Hanford Operations

H. Babad

L. C. Brown

J. L. Deichman

R. A. Deju

R. J. Gimera

D. R. Gustavson

E. J. Kosiancic

C. M. Manry

I. E. Reep

J. E. Roecker

D. D. Wodrich

File Copy
No. of

Copies

UNC United Nuclear Industries

T. E. Dabrowski

Westinghouse Hanford Company

A. G. Blasewitz

64 Pacific Northwest Laboratory

R. P. Allen

W. J. Bjorklund

W. F. Bonner

D. J. Bradley

J. L. Buelt

H. C. Burkholder

T. D. Chikalla

L. L. Clark

M. S. Hanson

J. H. Jarrett

A. B. Johnson, Jr.

S. E. King (3)

D. E. Knowlton

M. R. Kreiter

W. L. Kuhn

L. T. Lakey

R. C. Liikala

R. P. Marshal T

J. L. McEl roy

J. E. Mende $]$

J. E. Minor

J. F. Nesbitt (5)

R. E. Nightingale

S. G. Pitman (5)

A. M. Platt

W. A. Ross

J. M. Rusin/R. A. Brouns

S. C. Slate (15)

R. L. Treat

R. P. Turcotte

H. H. Van Tuyl

R. E. Westerman

E. J. Wheelwright

Technical Information (5)

Publishing Coordination (2) 
